\title{
Facies, depositional environment, and palaeoecology of the Middle Triassic Cassina beds (Meride Limestone, Monte San Giorgio, Switzerland)
}

\author{
Rudolf Stockar
}

Received: 18 June 2009/Accepted: 20 January 2010/Published online: 28 May 2010

(C) Swiss Geological Society 2010

\begin{abstract}
The Ladinian Cassina beds belong to the fossiliferous levels of the world-famous Middle Triassic Monte San Giorgio Lagerstätte (UNESCO World Heritage List, Canton Ticino, Southern Alps). Although they are a rich archive for the depositional environment of an important thanatocoenosis, previous excavations focused on vertebrates and particularly on marine reptiles. In 2006, the Museo Cantonale di Storia Naturale (Lugano) started a new research project focusing for the first time on microfacies, micropalaeontological, palaeoecological and taphonomic analyses. So far, the upper third of the sequence has been excavated on a surface of around $40 \mathrm{~m}^{2}$, and these new data complete those derived from new vertebrate finds (mainly fishes belonging to Saurichthys, Archaeosemionotus, Eosemionotus and Peltopleurus), allowing a better characterization of the basin. Background sedimentation on an anoxic to episodically suboxic seafloor resulted in a finely laminated succession of black shales and limestones, bearing a quasi-anaerobic biofacies, which is characterized by a monotypic benthic foraminiferal meiofauna and has been documented for the first time from the whole Monte San Giorgio sequence. Event deposition, testified by turbidites and volcaniclastic layers, is related to sediment input from basin margins and to distant volcanic
\end{abstract}

Editorial handling: Daniel Marty \& Andreas Wetzel.

R. Stockar $(\square)$

Museo Cantonale di Storia Naturale, Viale Cattaneo 4,

6900 Lugano, Switzerland

e-mail: rudolf.stockar@ti.ch

R. Stockar

Institut de Géologie et Paléontologie, Université de Lausanne,

Anthropole, 1015 Lausanne, Switzerland eruptions, respectively. Fossil nekton points to an environment with only limited connection to the open sea. Terrestrial macroflora remains document the presence of emerged areas covered with vegetation and probably located relatively far away. Proliferation of benthic microbial mats is inferred on the basis of microfabrics, ecological considerations and taphonomic (both biostratinomic and diagenetic) features of the new vertebrate finds, whose excellent preservation is ascribed to sealing by biofilms. The occurrence of allochthonous elements allows an insight into the shallow-waters of the adjoining timeequivalent Salvatore platform. Finally, the available biostratigraphic data are critically reviewed.

Keywords Cassina beds - Middle Triassic .

Monte San Giorgio · Facies · Palaeoecology ·

Depositional environment

\section{Introduction and geological setting}

The Middle Triassic sequence at Monte San Giorgio (Figs. 1, 2), inscribed in 2003 on the UNESCO World Heritage List because of its unique palaeontological value, consists of several distinct formations, overlying a pre-Permian metamorphic basement and a Permian volcanic succession. The lowermost formation is the Bellano Formation, a fluvio-deltaic sequence dated to the late Anisian (Illyrian) on the basis of its palynological content (Sommaruga et al. 1997). During the late Anisian a progressive transgression of a shallow epicontinental sea from the east took place, in consequence of which carbonate platforms began to grow (Furrer 2001a) north of an emerged land buried today under the Po Plain (Brusca et al. 1981; Picotti et al. 2007). Dolomitized microbial 
Fig. 1 Map of the Monte San Giorgio area showing the Middle Triassic carbonate sequence and the location of the excavation site of the Cassina beds near Cassina. Scale bar $1 \mathrm{~km}$

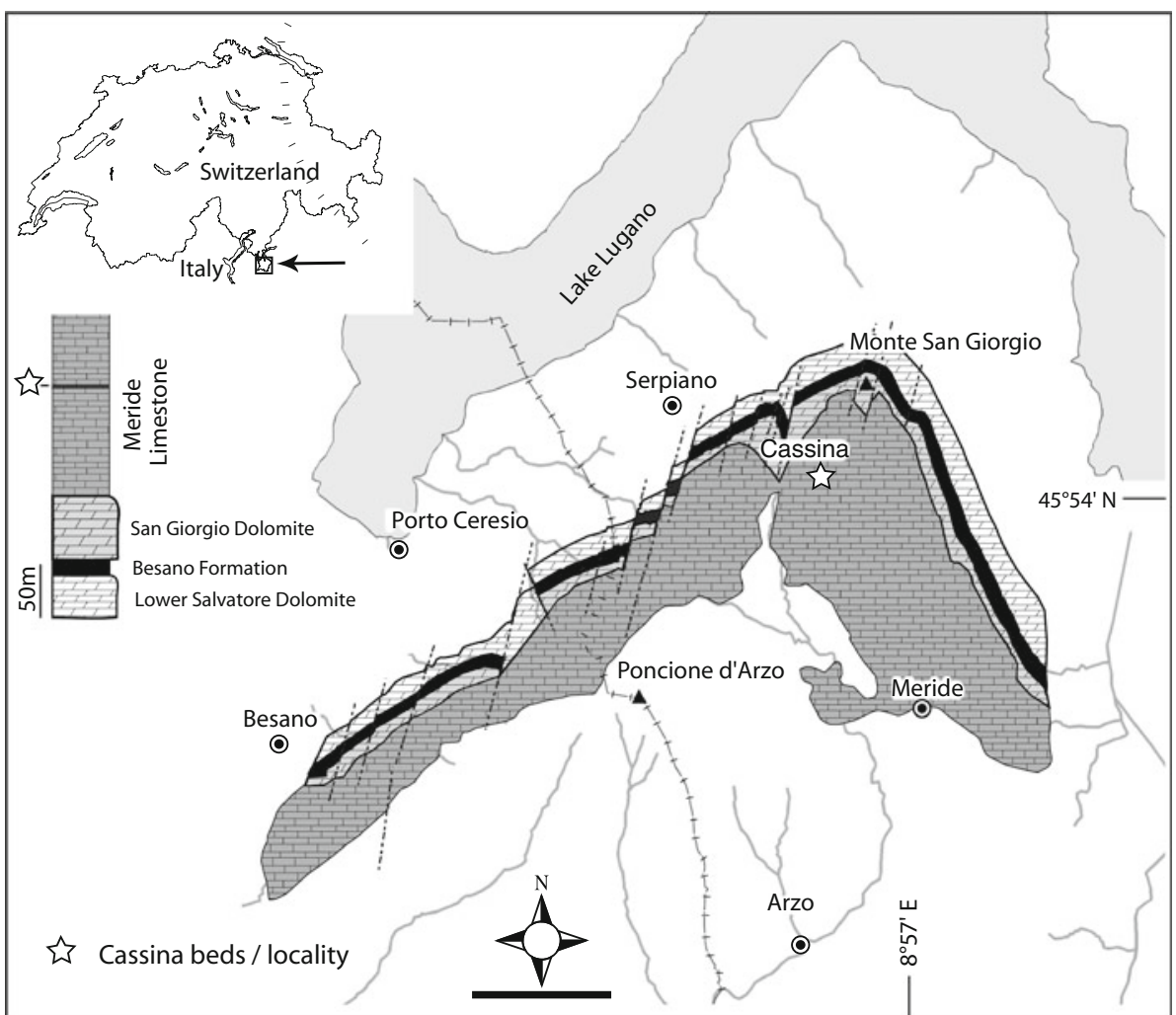

limestones, characterized by stromatolitic laminations (Lower Salvatore Dolomite), were deposited in a shallow subtidal to intertidal environment. During the latest Anisian and Ladinian, a 30-100 m deep intra-platform basin with restricted circulation developed in the Monte San Giorgio area (Bernasconi 1994; Furrer 1995), whereas in the north shallow-water sedimentation continued (Middle and Upper Salvatore Dolomites; Zorn 1971). Extensional tectonics have been suggested as a controlling factor for the intra-platform basin (e.g. Zorn 1971; Furrer 1995) but conclusive evidences are missing in the Monte San Giorgio/Monte San Salvatore area, where no Triassic tectonic structures are recognizable (Bernasconi 1994). In the Monte San Giorgio area, the Besano Formation was deposited on top of the Lower Salvatore Dolomite ("Grenzbitumenzone"; Frauenfelder 1916), and consists of an up to $16 \mathrm{~m}$ thick alternation of black shales and dolomites, including in its uppermost part the AnisianLadinian boundary (Röhl et al. 2001). A volcanic ash layer lying a few metres below this boundary yielded an $\mathrm{U}-\mathrm{Pb}$ minimum age of $241.2 \pm 0.8 \mathrm{Ma}$ (Mundil et al. 1996; Brack et al. 2007). Most of the spectacular vertebrate fossils (reptiles and fishes) together with important index fossils, including ammonoids and daonellid bivalves, come from this formation (Rieber 1969, 1973; Kuhn-Schnyder 1974; Bürgin 1992). The Besano Formation grades upwards into the approximately $60 \mathrm{~m}$ thick San Giorgio Dolomite followed by the 400-600 m thick
Meride Limestone (Frauenfelder 1916; Furrer 1995). The Besano Formation, the San Giorgio Dolomite and the Meride Limestone were deposited in the same basin, whose east-west extension is estimated to have been about $10 \mathrm{~km}$ or even $20 \mathrm{~km}$ if they were settled in the same basin as the Perledo-Varenna Formation (Gianotti and Tannoia 1988; Bernasconi 1994). As the Meride Limestone is considered to be the source rock of the oil of Trecate, Villa Fortuna and Gaggiano fields (Italy; Picotti et al. 2007) the intra-platform basin where it was deposited extended southwards for over $60 \mathrm{~km}$. The Besano Formation and the dasycladalean-rich Middle Salvatore Dolomite are roughly coeval, representing a basinal and a shallow-water facies, respectively. The San Giorgio Dolomite and the Meride Limestone are timeequivalent to the Upper Salvatore Dolomite, which shows the same intertidal to shallow subtidal facies as the Middle Salvatore Dolomite from which it is distinguished by a marker horizon bearing small bivalves (Zorn 1971). The Ladinian Lower Meride Limestone, $90 \mathrm{~m} \mathrm{(Wirz}$ 1945 ) to $150 \mathrm{~m}$ thick (Furrer 1995) consists of wellbedded limestones and marlstones with very rare bioturbation structures. As a whole, the Lower Meride Limestone is interpreted as a sequence of lime mud turbidites deposited under anoxic to dysoxic conditions (Bernasconi 1994). Three levels (Cava inferiore beds, Cava superiore beds and Cassina beds), consisting of finely laminated limestones and black shales with 
Fig. 2 Stratigraphic section of the Triassic sediments in the Monte San Giorgio area (modified and updated after Furrer 1995). Vertebratebearing beds and index fossils of the Meride Limestone are indicated

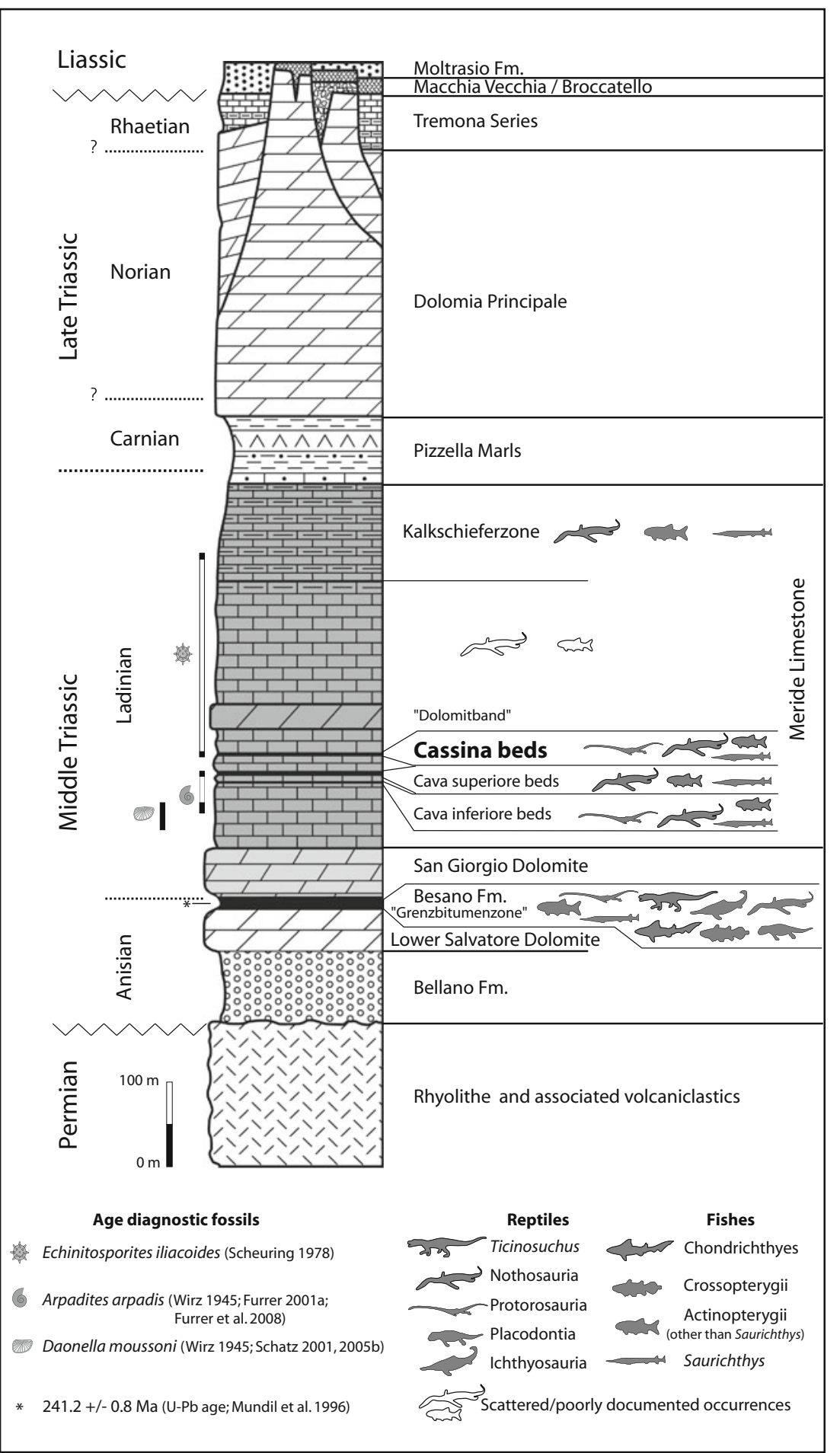

intercalated volcanic ash layers, are present in the upper part and yield different vertebrate assemblages. Organic carbon content averages around 1\% TOC (Picotti et al. 2007 ) but it reaches up to $20 \%$ in thin black shale layers (Bernasconi 1994). The top of the Lower Meride Limestone is defined by a dolomite marker bed ("Dolomitband"; Frauenfelder 1916), reaching a thickness of about $30 \mathrm{~m}$ (Wirz 1945; Furrer 1995). The overlying
Upper Meride Limestone is a sequence of alternating well-bedded limestones and marlstones with an increasing clay content towards the top. The uppermost part is the 120 m thick "Kalkschieferzone", made up of thin-bedded, laminated marlstones and claystones with peculiar fish faunas, crustaceans and arthropods. It represents the late evolution of the intra-platform basin, recording strong seasonal variations of salinity and water level and 
progressively buried by an increasing input of siliciclastic material (Furrer 1995).

On the Swiss side of Monte San Giorgio, from 1994 to 2005 a team from the Palaeontological Institute and Museum of the University of Zurich (PIMUZ), led by H. Furrer, studied a section of the Kalkschieferzone and both the Cava inferiore and the Cava superiore beds (Furrer 1995, 1999a, b, 2001a, 2003). Another team from the University of Milan (UNIMI), led by A. Tintori, carried out excavations in the Kalkschieferzone between 1997 and 2003 (Krzeminski and Lombardo 2001; Lombardo 2002; Lombardo and Tintori 2004; Tintori and Lombardo 2007). All these projects were co-ordinated and financially supported by the Museo Cantonale di Storia Naturale (Dipartimento del territorio del Cantone Ticino), the institution in charge of the management of the research activities as well as the housing of fossil specimens from the Monte San Giorgio UNESCO WHL site.

After conclusion of these projects, in 2006 the Museo Cantonale di Storia Naturale (Lugano) opened a new excavation in the Cassina beds, in order to investigate bed by bed the fossiliferous sequence. The new site (Swiss National Coordinates: 716'990/85'150; Fig. 1) is located about $50 \mathrm{~m}$ north of the outcrop excavated in the 1970s by the PIMUZ (see further below). Here, the Cassina beds represent an almost $3 \mathrm{~m}$ thick sequence, the upper third of which has so far been excavated on a surface of around $40 \mathrm{~m}^{2}$, passing upwards into thick-bedded dolomitic limestones and dolomites. The studied section mainly consists of interbedded finely laminated, organic-rich shales and limestones with intercalated thicker micritic limestones and tephra layers. The preliminary results of the first 3 years are presented here. The collected material is deposited at the Museo Cantonale di Storia Naturale, Lugano (MCSN).

\section{Historical remarks and previous finds}

The Cassina beds are named after the locality lying to the south of the Monte San Giorgio summit, where they were discovered in 1933 by the PIMUZ technical assistant Fritz Buchser. A first excavation was started in the same year by the PIMUZ, which carried out further excavations in 1937 , in 1971-1973 and in 1975 (Furrer 2003). The excavations yielded reptile fossils belonging to four species (KuhnSchnyder 1974): many pachypleurosaurids ascribed to Neusticosaurus edwardsii (Carroll and Gaskill 1985; Sander 1989), three specimens of the large nothosaurid “Ceresiosaurus" lanzi (Rieppel 1998, 2007; Hänni 2004) and two protorosaurs belonging to Macrocnemus bassanii (Peyer 1937) and to Tanystropheus meridensis (Wild 1980), respectively. The latter, a largely incomplete juvenile specimen, was regarded as conspecific with
Tanystropheus longobardicus by Nosotti (2007). The associated fish fauna turned out to be dominated by the basal actinopterygian Saurichthys (S. curionii and S. macrocephalus; Rieppel 1985). In addition, smaller actinopterygians ascribed to three different genera were also reported: Peltopleurus sp. (a single specimen described in Bürgin 1992), Archaeosemionotus sp. nov. and Macrosemiidae gen. et sp. nov. (both cited in Bürgin 1999 but undescribed and not figured so far). Reported microfossils include ostracods, foraminifers (Glomospira sp., Trochammina sp., Dentalina sp.; Wirz 1945) and palynomorphs (Scheuring 1978).

\section{Review of the biostratigraphic setting}

The Cassina beds are commonly regarded as early Ladinian in age (e.g. Hellmann and Lippolt 1981; Carroll and Gaskill 1985; Rieppel 1998) but the exact position of the early/late Ladinian boundary within the Meride Limestone is as yet unknown. Recently, Furrer et al. (2008, p. 602) tentatively correlated the Cassina beds with the lowermost Wengen Formation of the GSSP section at Bagolino (P. archelaus zone, late Ladinian; Brack et al. 2005).

Some biostratigraphic considerations regarding the Lower Meride Limestone are summarized here. Typical age-diagnostic fossils such as ammonoids and conodonts, requiring stenohaline surface waters, are rare within the Meride Limestone, a situation usually observed for landward basins restricted from open sea waters. In the lowermost part of the sequence, below the Cava inferiore beds, the following index fossils have so far been reported by previous authors (Fig. 2).

- Daonella moussoni (Frauenfelder 1916, p. 279; Senn 1924, p. 563; Wirz 1945, p. 49; Schatz 2005a, p. 192; Schatz 2005b, p. 100). Rieber (1969) attributed the material from the Frauenfelder and Wirz collections to Daonella aff. moussoni, whereas Schatz (2001, 2005b) considered Daonella aff. moussoni and D. moussoni as conspecific.

- Protrachyceras archelaus (Frauenfelder 1916, p. 279; Wirz 1945, p. 53) and Protrachyceras cf. archelaus (Senn 1924, p. 563). The material from the Wirz collection was redetermined by H. Rieber as Protrachyceras cf. ladinum (Schatz 2001).

- Arpadites arpadis (Wirz 1945, p. 54).

In the Cava superiore beds, about $40 \mathrm{~m}$ above the horizon mentioned previously and around $30 \mathrm{~m}$ below the Cassina beds, specimens of Arpadites cf. arpadis were collected by H. Furrer during the 1997-2005 excavations in collaboration with the MCSN (Furrer 2001a; Furrer et al. 2008). In the Southern Alps, ammonoids belonging to 
Arpadites range from the $P$. gredleri to the $P$. archelaus zone (Brack and Rieber 1993). In the GSSP section at Bagolino (Buchenstein Fm.) A. arpadis occurs at 70.5$75.6 \mathrm{~m}$, that is below and above the dated Middle Pietra Verde volcaniclastic layer $(72.2 \mathrm{~m}$, minimum $\mathrm{U}-\mathrm{Pb}$ age of $238.8+0.5 /-0.2 \mathrm{Ma}$ ), within the early Ladinian $P$. gredleri zone (Mundil et al. 1996; Brack et al. 2005, 2007). D. moussoni and Protrachyceras cf. ladinum indicate the P. gredleri zone as well (Schatz 2001). Accordingly, the Lower Meride Limestone up to and including the Cava superiore beds can confidently be attributed to the early Ladinian $P$. gredleri zone.

Ammonoids and daonellids have so far not been reported from the Cassina beds, making an age assignment more difficult. However, Scheuring (1978) reported two specimens of the palynomorph Echinitosporites iliacoides, the first one from his sample 90, coming from the excavation led at Cassina by E. Kuhn-Schnyder from 1971 to 1975, and the second one from his sample 103/106 (lower Kalkschieferzone; Fig. 2). E. iliacoides is an important marker fossil with a stratigraphic range restricted to the secatusdimorphus phase of Van der Eem (1983) and according to recent data from the Seceda core (Buchenstein Fm.) it is limited to the early late Ladinian $P$. archelaus zone (Hochuli and Roghi 2002). Moreover, on the basis of the occurrence of E. iliacoides, the Cassina beds correlate with the uppermost Reifling Formation (Northern Calcareous Alps), which is assigned to the $P$. archelaus zone as well (Kulm section; Brühwiler et al. 2007). In conclusion, according to available biostratigraphic data an age assignment of the Cassina beds to the early Longobardian (P. archelaus zone; early late Ladinian) cannot be ruled out.

\section{Lithofacies description and interpretation}

The classification of Dunham (1962) is followed here, keeping in mind that the greatest problem with this scheme lies in its strong relation to the depositional character of the textures, which may be affected by recrystallization and replacement, sometimes obliterative (Flügel 2004). Three distinct lithofacies groups are intercalated as thin to medium beds throughout the studied section (Fig. 3). All these are overlain by the dolomite lithofacies.

Laminite lithofacies

\section{Description}

Finely laminated, generally fissile, organic-rich black shales and limestones constitute the main part of the studied section and reflect the background sedimentation

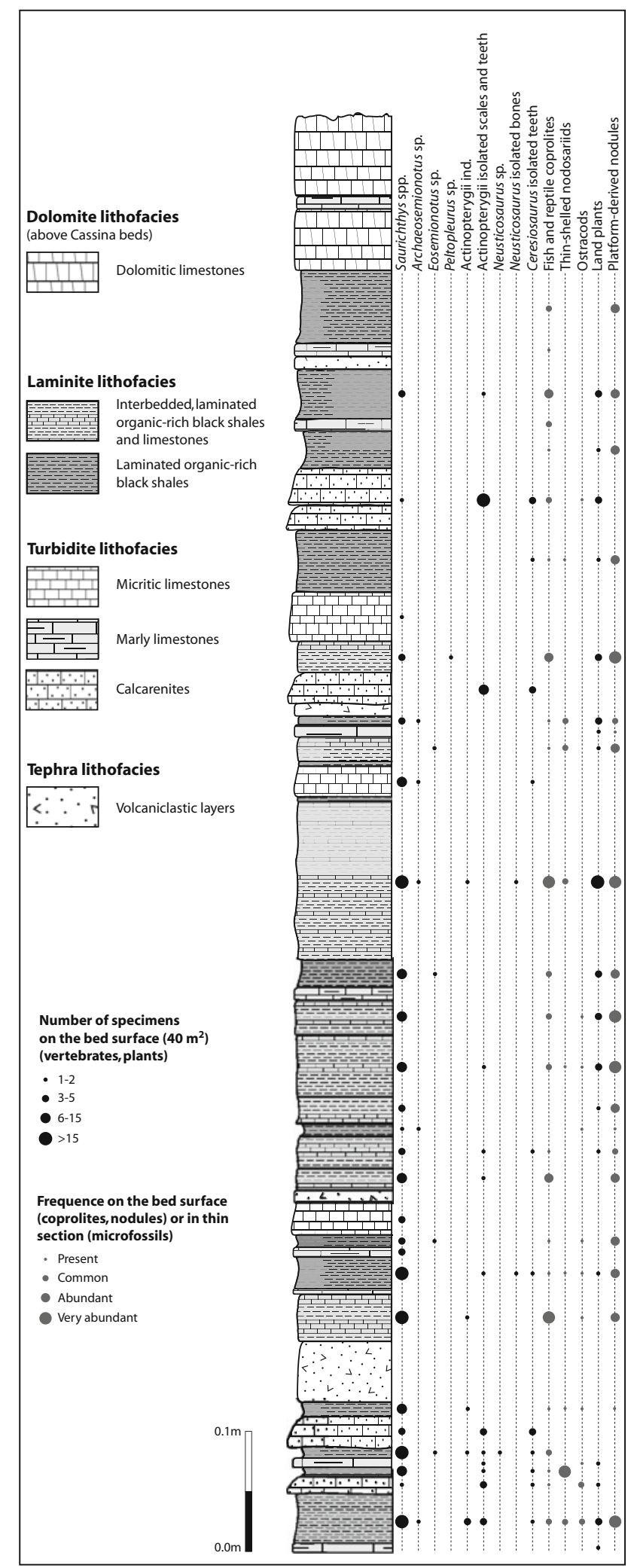

Fig. 3 Detailed sedimentological log of the investigated upper part of the Cassina beds with indication of the distribution and abundance of macro- and microfossils 
Fig. 4 Carbonate lithofacies of the Cassina beds. a-c Laminite lithofacies. a Polished section exhibiting the typical lamination of the background sedimentation. In addition, a thin turbidite layer is visible in the uppermost part. b Wavy alternation of irregular dark (organic-matter rich) and bright (calcisiltite) laminae.

Photomicrograph. c Bedding plane surface with non-sizesorted, thin-shelled nodosariid foraminifers. Photomicrograph. d-h Turbidite lithofacies.

d Normally graded lime packstone to lime mudstone; close-up view of the turbidite layer in the uppermost part of $\mathbf{a}$. Photomicrograph. e Reworked bioclasts (foraminifers). Photomicrograph. f Calcarenite sublithofacies. Lower bedding plane bearing a reworked, broken rostrum of a large Saurichthys (MCSN 8096, probably $S$. macrocephalus). g Micritic limestone sublithofacies. Polished section of a virtually structureless layer. Compare to plate $1, \mathrm{~b}$ in Bernasconi (1994). h Marly limestone sublithofacies.

Polished section. Scale bars $10 \mathrm{~mm}(\mathbf{a}, \mathbf{f}-\mathbf{h}) ; 0.5 \mathrm{~mm}(\mathbf{b}-\mathbf{e})$
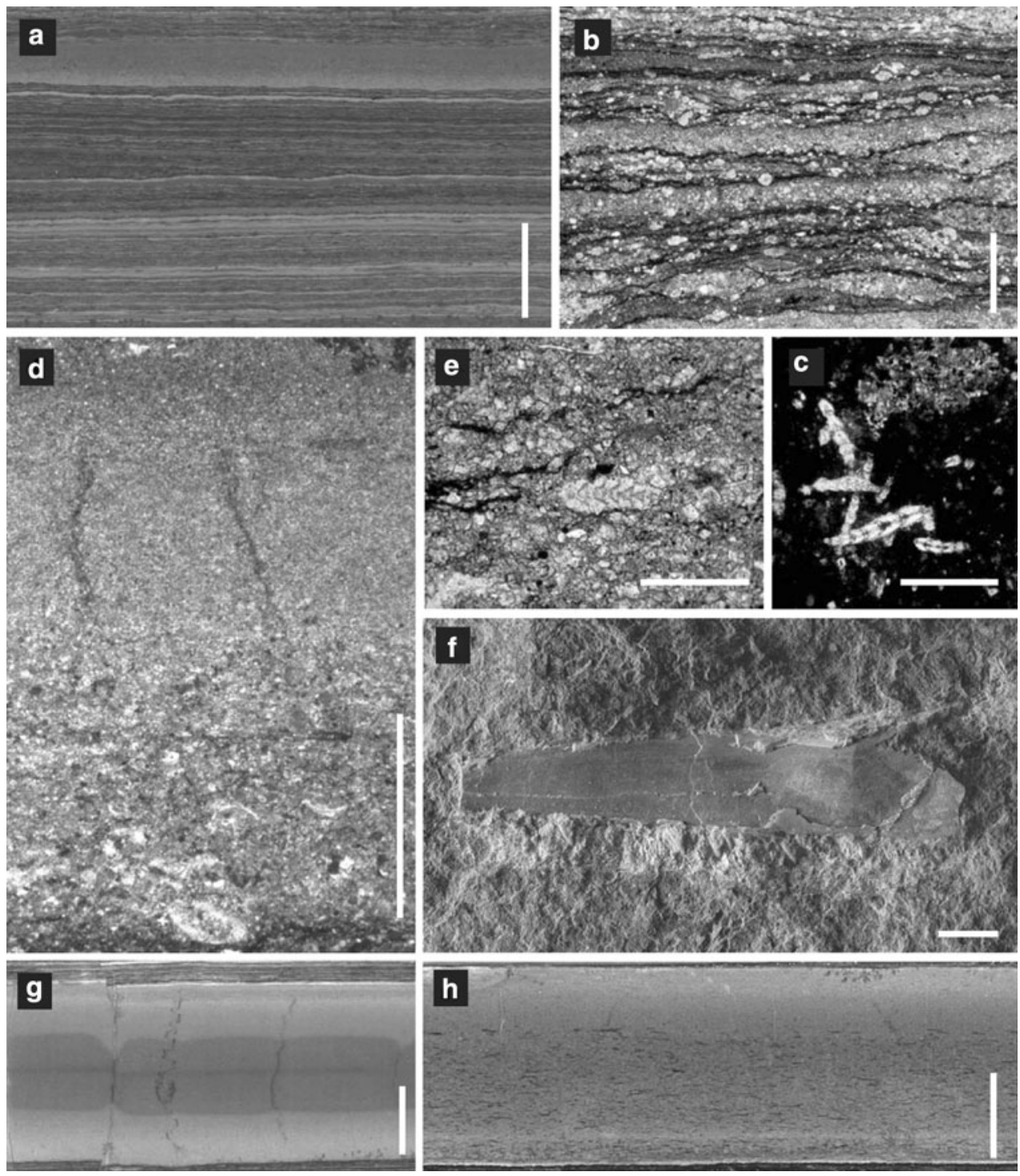

(Fig. 4a). This lithofacies is characterized by a microrhythmic pattern of irregular wavy dark and bright laminae between 30 and $300 \mu \mathrm{m}$ in thickness (Fig. 4b).

Dark laminae are enriched in organic matter forming seams and clusters; in addition, clay and sporadic mica are present. Bright laminae, usually thicker, show a prevailing packstone to grainstone texture with poorly preserved, platform-derived skeletal grains (mainly foraminifers and ostracods). Pyrite is present throughout the section, but usually in small amounts of evenly disseminated tiny crystals. Quartz grains are scattered within the fine to medium-sized silt fraction and framboidal pyrite inclusions suggest an authigenic origin (Bernasconi 1994). Vertebrates are usually preserved as articulated skeletons, whereas isolated bones, scales, and teeth are rare. Coprolites, measuring 5-50 $\mathrm{mm}$ and flattened carbonate nodules (see "Allochthonous platform-derived elements") are scattered on the bed surfaces. Only a monotypic foraminiferal meiobenthos is present (Fig. 4c; see further below), whereas benthic metazoan fossils are completely absent.

\section{Interpretation}

The preservation of the fine lamination indicates a complete absence of both bioturbation and physical reworking. The lamination may be derived from microbial mats, which grew on the seafloor (benthic mats), generating a framework resembling that of a supple tissue. Fine platform-derived detrital particles, carried into the basin as suspended load, could easily be trapped and fixed (Gall 2001). In the underlying Besano Formation, an important contribution of bacterial biomass to the preserved organic material can be inferred from high concentrations of hopanoid hydrocarbons, only known from prokaryotic 
organisms (Bernasconi 1994). Within the Lower Meride Limestone the occurrence of compacted mats of sulphur bacteria has been postulated by Furrer (1999a). The presence of microfabrics possibly related to benthic microbial mats suggests that also in the basin of the Cassina beds a major part of the organic matter was produced by bacteria.

The small-scale rhythmicity is likely related to recurrent variations of environmental conditions, influencing primary productivity and microbial activity, and above all controlling the supply of carbonate mud stirred up from the platform by wave and current action. Cyclic sedimentary patterns at different scales are evident in the Monte San Giorgio sequence. Chiefly relying on Zorn (1971), who suggested emersion periods of the Salvatore platform on the basis of vadose diagenesis indicators, sea-level fluctuations have been assumed as a possible control factor of the dmscale cyclicity characterizing the alternation of black shales and dolomites in the underlying Besano Formation (Bernasconi 1994). Although it cannot be ruled out, a periodic emersion of the Salvatore platform has so far not been substantiated by any field evidence such as unquestionable emersion surfaces (Bernasconi 1994). Whatever factor controlled the large-scale cyclicity characterizing the Besano Formation, sub-mm-scale rhythmicity as suggested by the laminite lithofacies of the Cassina beds may best be attributed to a strong seasonality. During Ladinian times, the depositional environment was located within the subtropical zone at a palaeolatitude of around $18^{\circ} \mathrm{N}$ (Brack et al. 1999) and was influenced by a monsoonal climate (Mutti and Weissert 1995). High-frequency fluctuations in climate, even on a seasonal scale, are well supported by sedimentological and early diagenetic data from the coeval Esino Platform (Mutti and Weissert 1995), which was located around $16 \mathrm{~km}$ east of the studied section (Bernasconi 1994).

The presence of dispersed pyrite provides evidence of a reducing environment within the sediment, where organic matter served as a reductant for seawater sulphate in anaerobic bacterial decay. The relatively low pyrite content, already noted in black shales from the underlying Besano Formation, is probably related to the severe iron limitation typical of carbonate depositional systems (Bernasconi 1994; Röhl et al. 2001). Even though the dark laminae contain fine siliciclastics, iron being incorporated in rather inert phases such as clay minerals it was probably poorly reactive (Allison et al. 1995).

This rhythmic pattern is sporadically interrupted by organic-poor lime mudstones, up to $5 \mathrm{~mm}$ thick, sometimes showing normally graded bedding (Fig. 4a, d). The very fine-grained layers, white to grey in hand specimen, are interpreted as short-lived events related to muddy turbidity currents. Their features are the same as those described for the micritic limestones belonging to the turbidite lithofacies.
Turbidite lithofacies

\section{Description}

This lithofacies includes calcarenites, micritic limestones and marly limestones, and ranges in thickness from $1 \mathrm{~mm}$ to $4 \mathrm{~cm}$ within the studied section. Only beds thicker than $5 \mathrm{~mm}$ are indicated in Fig. 3. Calcarenites usually show depositional couplets and erosional basal surfaces. Normally graded depositional couplets include a basal packstone/wackestone composed of silt-sized to medium sand-sized debris overlain by lime mudstone with only faint lamination; calcarenites bear a large number of reworked macrofossil fragments, mainly sauropterygian and fish teeth (among which conical "Saurichthys-type" teeth prevail), fish scales and bones. Even robust elements such as skull bones of large specimens of Saurichthys show evidences of fragmentation and abrasion under high-energy conditions (Fig. 4f). Non-articulated skeletons were found.

Primary depositional structures of the fine-grained micritic and marly limestones (wackestones to lime mudstones, less frequently packstones; Fig. $4 \mathrm{~g}, \mathrm{~h}$ ) are not always visible owing to recrystallization and diagenetic dolomite formation. However, unlike the calcarenites, micritic and marly limestone beds never display an erosional base and sometimes appear structureless (Fig. $4 \mathrm{~g}$ ) or with only a faintly laminated uppermost part. In addition, very thin floating black chips of up to few millimetres are often present in the marly limestones.

Layers belonging to the turbidite lithofacies bear poorly preserved microfossils, consisting of fragmented skeletal grains, mainly derived from reworked ostracods and foraminifers (Fig. 4d, e).

\section{Interpretation}

In agreement with the depositional models proposed for the Besano Formation (Bernasconi 1994) and for the PerledoVarenna Formation (Gaetani et al. 1992), this lithofacies is interpreted to record event deposition into a low-oxygen setting. The Perledo-Varenna Formation, early to late Ladinian in age and therefore time-equivalent to the Meride Limestone, was likely settled in the same intra-platform basin (Gianotti and Tannoia 1988) and more precisely in a similarly oxygen-deficient setting located around $15 \mathrm{~km}$ east of the Monte San Giorgio sequence (Bernasconi 1994) and limited by the Esino platform. The latter, in turn, represented the counterpart of the Salvatore platform in the Como region. Carbonate sediments compose up to $75 \%$ of the Perledo-Varenna Formation and systematic facies analysis carried out by Gaetani et al. (1992) on different sections identified ten main lithofacies. The above-described calcarenites match well the "facies PCg" of Gaetani 
et al. (1992), whereas micritic and marly limestones mainly compare with the "facies MWm/1" and the "facies Ma (type c)", respectively. Moreover, micritic limestones match the "white dolomite layers" (usually graded but sometimes structureless) described by Bernasconi (1994, p. 25) from the Besano Formation. According to the models proposed by the above authors and to new observations, the allodapic limestones of the turbidite lithofacies may be interpreted as follows:

- The calcarenite sublithofacies (Fig. 4f) is inferred to record episodic deposition from high-concentration lime turbidity currents (Gaetani et al. 1992). Taking into account both the bioclastic content and sedimentological features, initiation of the flow might have been triggered by slope failure along the directly adjoining margin of the Salvatore platform.

- The micritic limestone sublithofacies (Fig. 4g) is interpreted to represent carbonate mud eroded by major storm events from the shallow-water Salvatore-Esino platform system that surrounded the basin and then carried into the latter by dilute lime mud-dominated turbidity currents (Gaetani et al. 1992) and/or by detached lime mud-dominated turbidity currents favoured by water stratification (Bernasconi 1994).

- The marly limestone sublithofacies (Fig. 4h) is suggested to record episodic deposition from dilute lime mud-dominated turbidity currents (Gaetani et al. 1992). The floating black chips likely represent rip-up clasts from previously deposited organic-rich laminae. Data from the ongoing excavation highlight the close association between at least some of these beds and concentrations of terrestrial plant remains, which are usually of worn appearance and located within the very first lamina of the overlying laminite bed. This suggests, at least in some cases, long-term transport and deposition by hyperpycnal flows from rivers in flood, the delayed settling of plant remains resulting in discrete plant-rich laminae. Possible source area could be the emerged southwestern borders of the Meride Limestone basin (see figure 2 in Picotti et al. 2007). This aspect will be further investigated in the near future by means of both macroflora and palynofacies analysis.

Tephra lithofacies

\section{Description}

The Cassina beds bear a large number of discrete bentonite layers, derived from the alteration of volcanic ash, ranging in thickness from $<1 \mathrm{~mm}$ to $5 \mathrm{~cm}$ within the studied $\mathrm{sec}$ tion. They usually show distinct gradation with a sand- sized layer at the base and, as they weather to an orange colour, they are easily detectable in outcrop. Bentonites are usually barren of any carbonate allochemical constituents.

\section{Interpretation}

The absence of carbonate allochemical constituents together with the widespread occurrence of very thin layers suggests an airborne origin with predominant sedimentation through subaqueous suspension-fall of ash following important, however far-away, subaerial eruptions. This assumption of an essentially primary origin substantially agrees with previous investigations on bentonites occurring within the underlying Besano Formation (Müller et al. 1964; Hellmann and Lippolt 1981) and rules out secondary transport and reworking. Zorn (1971) stressed that in the coeval adjacent Salvatore platform similar layers are missing and challenged this view. However, in this respect, it is worth mentioning that Bernoulli et al. (1976) reported the occurrence of a tephra bed within the upper part of the Salvatore Dolomite at Brusimpiano (Italy). At least a local lack of volcaniclastic intercalations is also known from the Buchenstein Formation area (Pietra Verde layers), where along the flanks and in the interiors of carbonate platforms these layers are found only sporadically (Brack and Rieber 1993 ) but, in spite of this, several of the Pietra Verde layers have been proven to be primary volcanic ash beds. It is possible that the volcaniclastic fallout in the platform settings has been washed out (Brack and Rieber 1993), adding to the background sedimentation in the adjacent basins.

\section{Dolomite lithofacies}

\section{Description}

The studied section is overlain by thick-bedded, finegrained dolomitic limestones and dolomites, usually organic matter-poor and grading upwards into the "Dolomitband". Recrystallization usually obliterates the depositional fabric, and only scattered, extremely poorly preserved skeletal grains derived from ostracods, bivalves and foraminifers are present. The microfabric exhibits a calcite and dolomite mosaic and can be classified as a microsparstone (Wright 1992).

\section{Interpretation}

Above the Cassina beds, that reflect oxygen-depleted conditions, the sudden onset of a more massive carbonate deposition suggests a switch to at least partial oxygenation of the bottom waters or to increased carbonate sediment input from the basin margins, but conclusive evidences are lacking due to the obliterative recrystallization. However, 
Fig. 5 Preservation patterns in Saurichthys curionii (laminite lithofacies). a Typical preservation pattern: articulated skeleton preserved in lateral position (MCSN 8013). b Disarticulated skeleton (MCSN 8075). c Deformation and displacement of skeletal elements at the level of the abdominal cavity (MCSN 8016). Scale bars $50 \mathrm{~mm}$
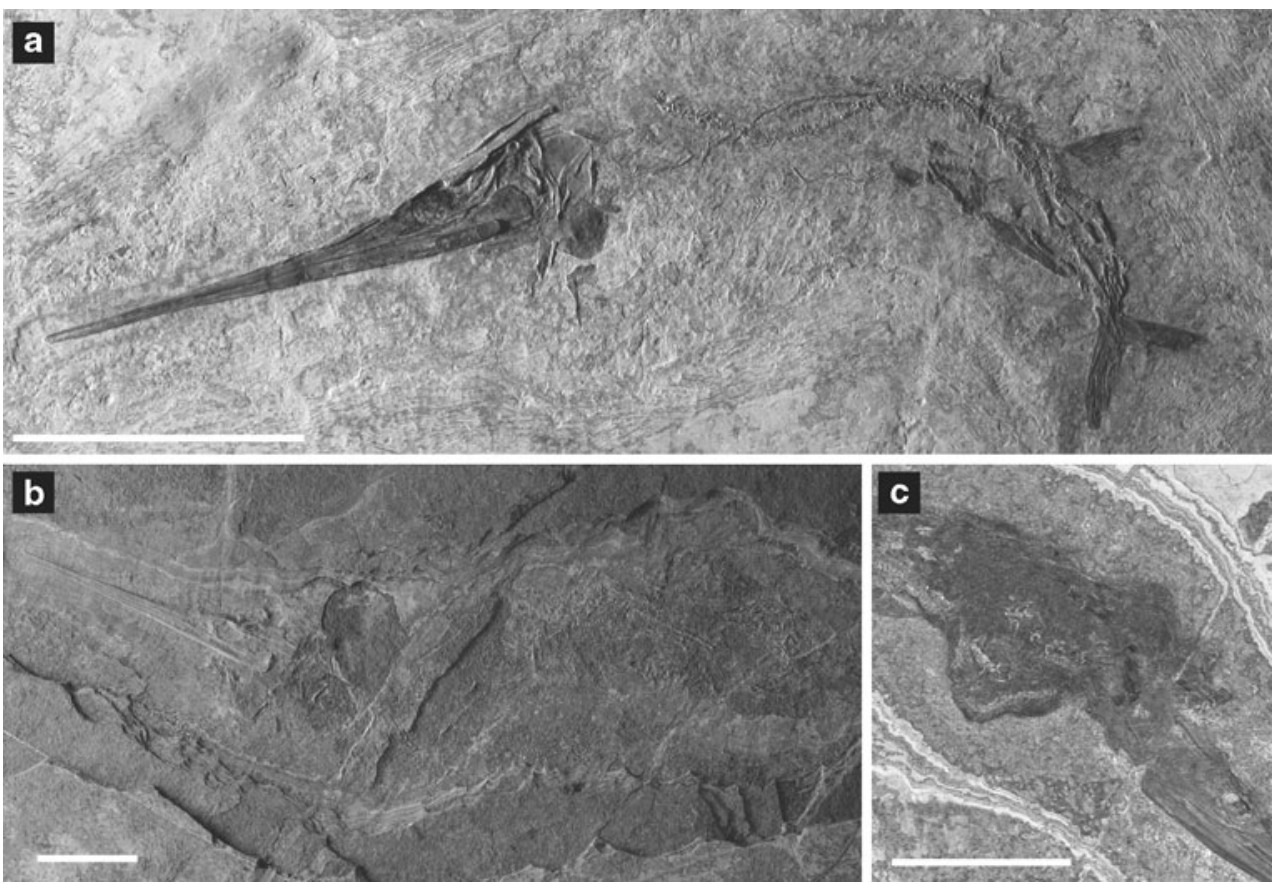

as a carbonate sediment input from the surrounding platforms is more consistent with sedimentological features of the underlying section, this interpretation seems more plausible. Accordingly, the dolomite lithofacies is assumed to be a partly dolomitized counterpart of the turbidite lithofacies, likely derived from thick-bedded micritic limestones (see also facies Dm/1 of Gaetani et al. 1992, p. 341).

\section{Macrofossils}

\section{Vertebrates}

The new excavation brought to light a fossil fish fauna composed of at least five species with four different feeding strategies. The large predatory actinopterygian fish Saurichthys with more than 200 specimens representing about $90 \%$ of the fish finds is clearly dominating (Fig. 5), and the recovered specimens document a complete growth series from (prenatal) embryo to adult. Fifteen specimens have been prepared and are mainly identified as S. curionii, characterized by a long and slender rostrum, a rather weakly developed dentition and a rounded operculum (Rieppel 1985). Individuals reach up to $44 \mathrm{~cm}$ in standard length. Four of them contain preserved embryos (Renesto and Stockar 2009). The bulk of the unprepared material appears to be referable to $S$. curionii as well, with specimens mainly between 20 and $45 \mathrm{~cm}$ long.
S. macrocephalus is only represented by fragmentary specimens.

Ten as yet unprepared specimens are clearly larger and possibly belong either to $S$. macrocephalus, which tends to get somewhat longer than $S$. curionii (whose adult standard length ranges between 30 and $46 \mathrm{~cm}$; Rieppel 1985), or to a new taxon, as suggested by Rieppel (1992). However, Rieppel (1992, p. 66) does not rule out the occurrence of exceptionally large $S$. curionii within the Cassina material. Saurichthys is regarded as an ambush predator hunting in the water column (Rieppel 1985; Gozzi 2001), and specimens from the Monte San Giorgio area are considered to have inhabited reef environments (like modern Fistularia; Rieppel 1985). Among the ichthyofauna of the studied section, it is unquestionably the top predator (see also Müller-Merz et al. 2005, fig. 27).

Medium- to large-sized fishes $(15-20 \mathrm{~cm}$ in standard length) are so far represented by nine specimens of the neopterygian Archaeosemionotus sensu Bürgin et al. (1991) (Fig. 6a, c) with a well-developed semi-durophagous dentition and a unique cheek-bone mosaic including numerous suborbitals (Bürgin 1995, p. 817; Bürgin et al. 1991, p. 955; Renesto et al. 2008, p. 129). This genus was established in 1889 by Deeke on a single, poorly preserved specimen from the Ladinian of the Perledo-Varenna Formation but an exhaustive description of diagnostic characters is still missing (see also Tintori and Lombardo 2007 for a critical review of nomenclatural problems in Archaeosemionotus). The new, complete and excellently 
Fig. 6 a-c Preservation patterns in Archaeosemionotus sp. (laminite lithofacies). a Typical preservation pattern with articulated postcranial skeleton and disarticulated skull (MCSN 8009). b The least disarticulated skull (MCSN 8073). c Disarticulated skull with bone dispersal (MCSN 8007). d-e Preservation patterns in Eosemionotus sp. (laminite lithofacies). d Partial disarticulation and dispersal of the peripheral skeletal elements (MCSN 8006). e Detail of the skull of MCSN 8006 shown in d. Scale bars $10 \mathrm{~mm}$
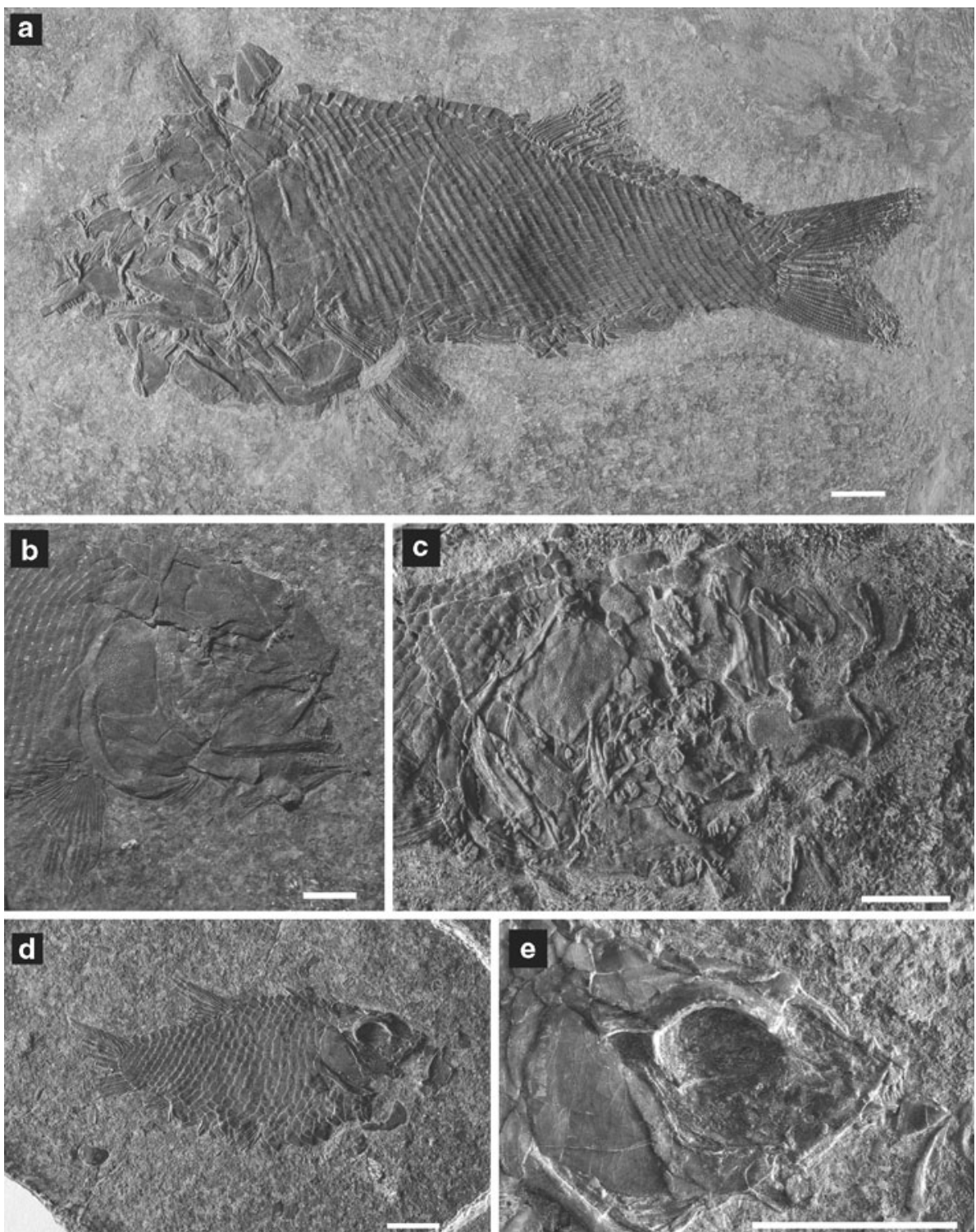

preserved material is expected to permit a careful revision of this genus and to shed light on its relationships with semionotiforms.

Three specimens belonging to Eosemionotus (Fig. 6d, e), 3-6 cm in standard length, represent the first record of this genus from the Cassina beds. Eosemionotus has been reported from all the vertebrate-bearing beds of Monte San Giorgio underlying the Cassina beds (Bürgin 1999; unpublished data of the MCSN from a small excavation carried out in 2008 in the Cava superiore beds, Swiss National Coordinates: $717^{\prime} 000 / 85^{\prime} 510$ ). Even though only a single species has so far been formally describednamely E. ceresiensis from the Besano Formationaccording to Bürgin (2004) four other morphotypes are present within the Monte San Giorgio sequence. The three specimens from the Cassina beds differ from E. ceresiensis by several characters, including a lower number of scale rows and a higher number of dorsal fin rays. Both the latter characters better match the type species $E$. vogeli from the Middle Muschelkalk (Schultze and Möller 1986), but the Cassina specimens differ from the type species in other features such as the shape of the gill cover, which bears a shield-like instead of a squarish operculum. The elongate and forwardly pointing teeth of Eosemionotus (Fig. 6e) were likely effective for picking small invertebrates from the bottom (Bürgin 2004).

The small basal actinopterygian Peltopleurus, around $2.5 \mathrm{~cm}$ in standard length, probably a schooling fish feeding on small planktonic invertebrates (Furrer 1995), completes the ichthyofauna prepared and determined so far. Peltopleurus is characterized by a typical squamation with a longitudinal row of dorso-ventrally deep flank scales 
covering almost two-thirds of the body depth. It occurs widely throughout the Middle Triassic Monte San Giorgio sequence, showing an impressive morphological variability (Lombardo 2001).

Reptiles turned out to be rare in the upper part of the Cassina beds. The only articulated find is a small specimen belonging to the genus Neusticosaurus, which probably inhabited shallow waters, preying on invertebrates and small fish (Sander 1989; Furrer 2003, fig. 28).

Pelagic, open-marine vertebrate taxa are completely missing. Thus, the vertebrate oryctocoenoses, and the absence of stenohaline ammonoids, point to an environment separated from the open ocean by a shallow-water platform, possibly partly reef-structured and providing a diversified habitat (Furrer 1999b; Müller-Merz et al. 2005).

\section{Terrestrial plants}

More than 50 terrestrial plant remains, ranging from $1 \mathrm{~cm}$ long leaves to $15 \mathrm{~cm}$ long shoot fragments, have so far been recovered. In addition, small coalified fragments are widespread as scattered remains. Only fragments larger than $1 \mathrm{~cm}$ are indicated in Fig. 3. Conifers are most abundant (Fig. 7), but seed ferns and probably other groups are represented as well.

The occurrence of plant remains confirms the presence of emerged areas covered with vegetation, as already indicated by the find of the terrestrial protorosaur Macrocnemus, which was previously reported from the Cassina beds (Peyer 1937). Floral composition, likely strongly taphonomically biased, and preservation of the specimens point to a source area other than the directly adjoining platform and relatively far away. A detailed study of the recovered macroflora is currently in progress (Stockar and Kustatscher, in press).

\section{Microfossils}

The finely laminated organic-rich black shales and limestones (laminite lithofacies) bear a poorly diverse microfossil assemblage. The following descriptions derive from thin-section observations.

\section{Foraminifers}

Foraminifers form a peculiar monotypic benthic assemblage composed of thin-shelled nodosariids (suborder Lagenina) with elongate and arcuate tests (Fig. 4c). Individuals occur in different amounts throughout the section; usually scattered, in some parts they are absent whereas elsewhere they occur in large numbers. In the latter case, the oryctocoenosis is composed of randomly oriented, non-size-sorted, well-

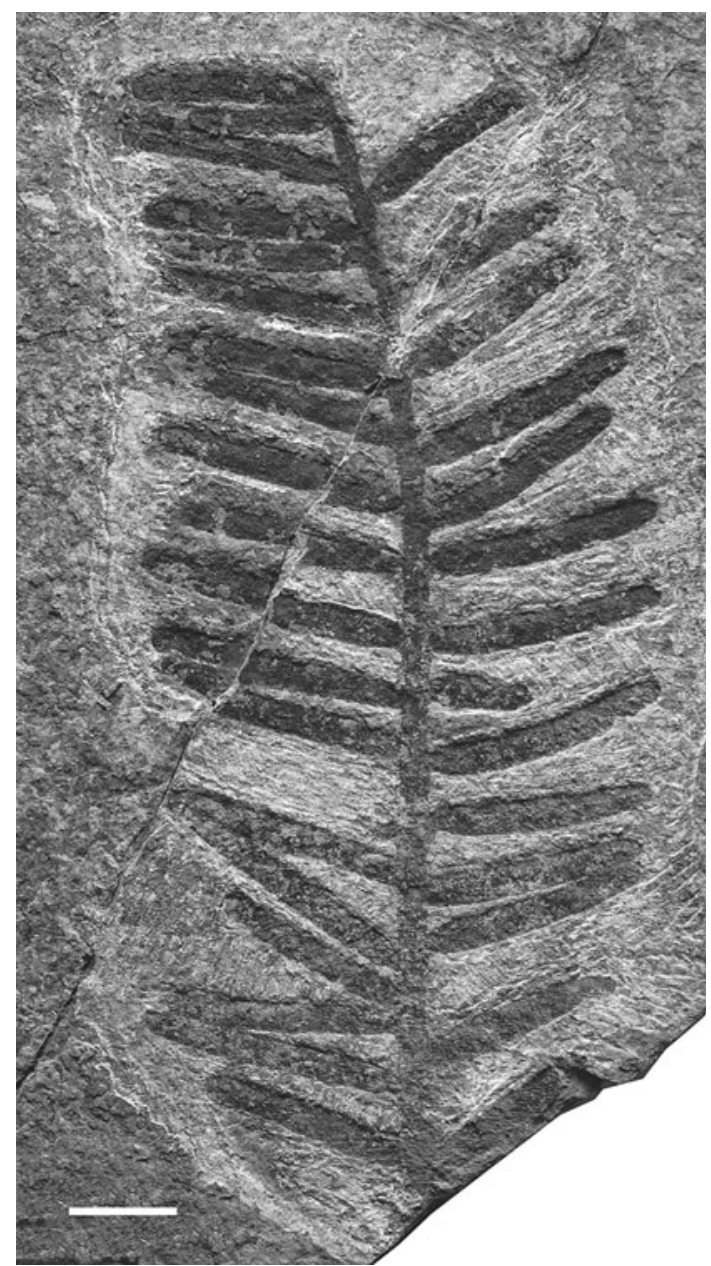

Fig. 7 Coniferal shoot fragment (MCSN 8039). Scale bar $10 \mathrm{~mm}$

preserved tests exhibiting different ontogenetic stages, between 50 and $600 \mu \mathrm{m}$ long (mean around $200 \mu \mathrm{m}$ ).

This is typical for autochthonous assemblages of benthic foraminifers (Holcova 1997; Murray 2006). The varying three-dimensional patchy (laterally and vertically within the sediment) distribution is likely to be due to the effects of varying microenvironments and reproduction. It recalls the peculiar ecological microdistribution pattern of living benthic foraminifers ("pulsating patches" of Buzas et al. 2002), providing further evidence for an indigenous assemblage. Feeding experiments show that benthic foraminifera are capable of pulling up pieces of biofilm taking bacteria into food vacuoles (Bowser et al. 1985). Benthic microbial mats and related high bacterial productivity assumed for the laminite lithofacies could represent a major factor for the sustenance of these populations. Random orientation of the uniserial tests on bedding surfaces (Fig. 4c) suggests the absence of bottom currents. The described thin-shelled, monospecific to paucispecific assemblage accounts for a benthic community colonizing a low-energy muddy seafloor and stressed by low 
bottom-water oxygen values (Murray 2006; see also further below).

\section{Ostracods}

Small ostracod carapaces occur within several beds belonging to the laminite lithofacies, yet their abundance never equates that of nodosariid foraminifers. In addition to the fact that only a few taxonomically important criteria can be evaluated from thin sections, paucity and usually poor preservation of the carapaces, mostly strongly recrystallized, prevent any important ecological indicators being determined. In absence of such parameters as the adult/juvenile ratio it is impossible to reliably assess whether the assemblage was definitely autochthonous. On the other hand, it cannot a priori be excluded that ostracod occurrences represent in situ populations as well.

\section{Vertebrate taphonomy}

The preservation of vertebrate remains closely depends on the lithofacies. The turbidite lithofacies contains only isolated bones and scales as detrital elements (Fig. 4f), the tephra lithofacies is barren of fossils. The laminite lithofacies displays different preservation pathways, allowing some taphonomic considerations, which are summed up here. Most of the vertebrate fossils are complete and preserved without, or with only partial, disarticulation. In the latter case, dispersed body parts are in spatial proximity to the rest of the skeleton. Isolated skeletal elements are very rare. Disarticulation pathways clearly vary between representatives of different species. Both specimens of Peltopleurus (MCSN 8002, 8003) are complete and one is strongly arched, the vertebral column is broken and the skull lies upside down on the back. This latter preservation pattern points to a complete anoxic bottom environment (Wilson 1988; Tintori 1992).

Archaeosemionotus (Fig. 6a, c) is characterized by a peculiar skull composed of a complex mosaic of small bones, which make it especially vulnerable to decaying processes. Unlike the usually undisturbed posterior part of the body (except for the most distal fin elements), skull bones are always more or less disarticulated though substantially remaining within the skull region. This preservation pattern indicates a bacterial decay process causing gas expulsion with related vibrations, leading to the decomposition of connective tissue and, consequently, to disarticulation. This is further supported by the observation that bacteria more easily grow in head cavities than in the postcranial region (McGrew 1975). Only one specimen of Archaeosemionotus (Fig. 6c) shows skull bones displaced in random directions, a typical characteristic of skeletons scavenged by necrophages (Wilson 1988), which prefer the head to the muscular area of the body (Elder and Smith 1988). Scavenging, in turn, would exclude anoxia from bottom waters and would imply at least temporary dysoxic conditions.

Eosemionotus specimens show no distortion. Two small specimens (MCSN 8005, 8078) are articulated up to the most distal elements of the fins. A larger specimen (Fig. 6d, e) shows dispersal of peripheral scales, fin elements and skull bones. Lepidotrichia, representing hydrodynamically light elements, are scattered behind the fins, whereas scales and skull bones are partly displaced around the body. This specimen may represent evidence of action of both hydrodynamic processes, related to gentle currents, and biologic processes, due to soft-bodied nonfossilizing necrophages.

Saurichthys shows the widest preservation patterns. Usually, specimens are articulated and preserved in a lateral position (Fig. 5a) like the other actinopterygians recovered so far. In one specimen (MCSN 8089) the skull is three-dimensionally preserved and exposed in dorsal view with a disarticulated lower jaw (similar to the specimen PIMUZ T835 from the Besano Formation, see figure 2 in Rieppel 1985), whereas the body is twisted, lying on its side. A further specimen shows the skull in lateral position and a fully disarticulated body without evidence of unimodal dispersal (Fig. 5b). Unlike the other fishes provided with heavy ganoid scale covering, specimens of Saurichthys may show evidence of decay-gas release from the body cavity causing deformation and/or displacement of the vertebral column and scale rows at the level of the swollen abdominal cavity (Fig. 5c).

The specimen ascribed to Neusticosaurus (MCSN 8076) is mostly articulated and exposed in ventral view, as also reported for most pachypleurosaurids from the Cava inferiore and Cava superiore beds. This preservation pattern is ascribed to gases developing in the wide abdominal cavity which held the body with the ventral side upward (Furrer 2003).

The systematic measuring of azimuthal orientation of skeletons on bedding plane surfaces and their preliminary preparation does not document any unimodal displacement of carcasses (Fig. 8).

The above-described preservation patterns indicate that also the partially disarticulated fish reached the sea bottom as complete bodies soon after death and that all processes of decomposition occurred on the seafloor. As even anaerobic decay leads to disarticulation within a short time (days to a few weeks; Brett and Baird 1986), the prevailing articulated preservation in the laminites may be related to the rapid growth of microbial mats. The coating of skeletons by biofilms may have protected the carcasses from decay, holding skeletal elements together (Seilacher et al. 


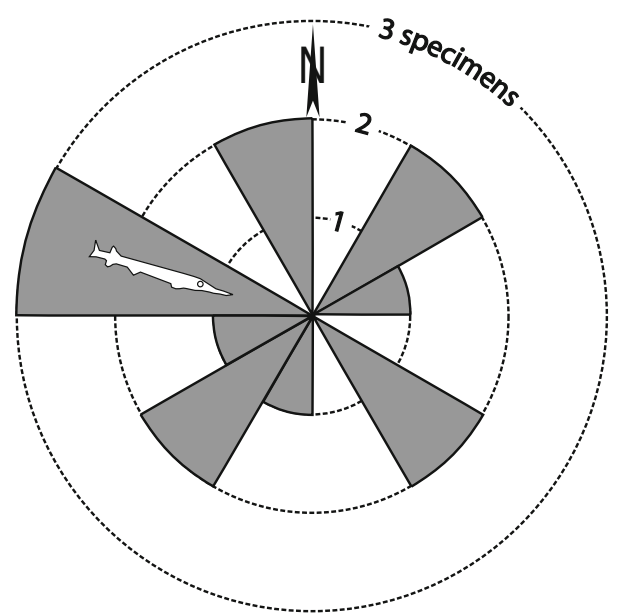

Fig. 8 Azimuthal orientation of Saurichthys specimens on the bedding plane of bed 29

1985) and allowing the preservation of delicate skeletons, such as those of Saurichthys, which are mainly articulated ("microbial shroud" effect; Gall 2001). The random dispersal of skeletal elements shown by some of the abovedescribed fish specimens is not necessarily conclusive evidence of scavenging; bacterial decay processes could entirely have resulted in the same preservation patterns, especially if the growth of microbial mats and the consequent bio-armouring effect were temporarily or spatially (if a patchy growth is assumed) reduced. Moreover, limiting the diffusion of chemical elements, the sealing effect of these biofilms creates particular geochemical microenvironments favourable to mineralization. This latter effect may account for the preservation of the fine structure of soft parts observed in some embryos of Saurichthys (Renesto and Stockar 2009).

The lack of uni-directional displacement of carcasses excludes stronger, persistent bottom current action. It should be noted, however, that the data plotted in Fig. 8 are subject to some limiting constraints. Even though only morphologically similar elements are considered (i.e. only elongated fishes such as Saurichthys), a wide range of sizes composes the data set, which as a consequence includes elements behaving differently from a hydrodynamic point of view. A more accurate investigation should be based on the azimuthal orientation of isolated parts (bones, scales) detached from different skeletons lying on the same bed. This requires a large amount of specimens to be prepared up to the finest elements, and such data may be available in the near future.

The very rare scattered, isolated skeletal elements could be interpreted as having dropped down after progressive disintegration of floating carcasses. However, postmortem buoyancy hardly applies to Triassic marine fishes, owing to their heavy ganoid scales, which prevented the carcasses from rising due to the accumulation of decay gas (Tintori 1992). Accordingly, this interpretation proves untenable as far as "heavy" forms such as Archaeosemionotus, Eosemionotus and Peltopleurus are concerned but might apply to Saurichthys, which lacks a heavy surface scale covering and is by far the most represented fish within the isolated bone material. In addition, regurgitation of prey items could be taken into account.

\section{Benthic fauna and bottom-water oxygenation}

The level of dissolved oxygen in the bottom environment has long been recognized as a chief control factor of benthic biota composition and its fundamental principle that decreasing oxygen values lead to a reduction in species diversity, and ultimately to mass mortality, has essentially remained unchallenged (e.g. Rhoads and Morse 1971; Allison et al. 1995). The only benthic taxa which may here be reliably considered autochthonous, are the thin-shelled nodosariids. Overall it seems that among the benthic fauna, meiofaunal taxa are less affected by oxygen-depletion than macrofauna, since the metabolic rate of unicellular organisms is lower than that of multicellular ones of equal mass (e.g. Moodley et al. 1997; Gooday et al. 2000; Murray 2006). Among the meiofauna, foraminifers seem to be the most tolerant to low oxygen concentrations (e.g. Josefson and Widbom 1988; Moodley and Hess 1992). Some extant foraminifer species are facultative anaerobes surviving prolonged anoxia and even sulfidic conditions for periods from a few weeks up to months; only a prolonged anoxia, of around 6 months, would ultimately be lethal (Bernhard and Reimers 1991; Moodley et al. 1997; Bernhard and Sen Gupta 1999). Moreover, as calcite secretion takes much more energy under dysoxic than oxic conditions (Rhoads and Morse 1971), it is generally accepted that oxygen consumption can be reduced by the secretion of an extremely thin shell. In addition, it is worth mentioning that extant counterparts such as thin-shelled Dentalina species (morphologically very similar to the nodosariid forms of the studied section) are regarded as "dysoxic indicators" typical for the 0.1-0.3 ml/l dissolved-oxygen range (Kahio 1994). Taking all this into account, the monotypic thinshelled nodosariid assemblages from the laminite litofacies can be regarded as representing euryoxic populations (Tyson and Pearson 1991), probably resistant to periodic anoxic conditions. Furthermore, the observed vertical distribution, marked by irregular occurrences and densities throughout the studied section, suggests an opportunistic behaviour. Probably the thin-shelled nodosariids survived in small numbers for long periods, even when circumstances were far from optimal, and as conditions changed in their favour, their population rapidly grew. 
Among ostracods, filter-feeding species can be low oxygen tolerant. Depending on their particular nutrition strategy, these forms create an enhanced circulation over their ventral respiratory surface. This, in turn, increases access to available oxygen and improves the survival potential, even under severe oxygen-depleted conditions (Whatley 1992; Lethiers and Whatley 1994; CrasquinSoleau and Kershaw 2005). Accordingly, the occurrence of ostracods within the laminite lithofacies would not be a priori ecologically inconsistent with the foraminiferal record. However, as it is questionable whether the ostracods actually represent in situ assemblages they are not considered here.

In order to evaluate the bottom-water palaeo-oxygenation, both sediment fabric and species diversity are taken in account. As the observed monotypic (or severely impoverished) community of the background sedimentation completely lacks benthic and nektobenthic macrofauna, it can be classified as oxygen-restricted biofacies (ORB) 1 of the ORB classification scheme proposed by Wignall and Hallam (1991). ORB 1 is equivalent to the anaerobic biofacies. The vertical distribution of the in situ benthic meiofauna, which can be prolifically (and episodically) abundant on some bedding planes, somehow recalls that typical for ORB 4, which is equivalent (Allison et al. 1995) to the "poikiloaerobic biofacies" (Oschmann 1991); the latter, in turn, results from the low-diversity, opportunistic benthic fauna responding to fluctuating (seasonally induced?) but generally low bottom-water oxygen values. In severe, and particularly in extreme poikiloaerobic biofacies, monospecific associations dominate (Oschmann 2001). Unfortunately, all the above-mentioned classification schemes are based on macro- and not on meio(micro)indicators. As a consequence, the term "quasi-anaerobic biofacies", introduced first by Koutsoukos et al. (1990) is here preferred to describe the benthic composition of the background sedimentation, since it explicitly relates to a facies characterized by a laminated sediment fabric, without (fossilizing) macrofauna but bearing an in situ microfauna. Tyson and Pearson (1991) regarded the occurrence of this biofacies as being limited to the $0.0-0.2 \mathrm{ml} / \mathrm{l}$ dissolved-oxygen range and used the term "suboxic" for the corresponding environmental conditions. The upper limit of $0.2 \mathrm{ml} / 1$ is crucial because it is the critical oxygen concentration below which macrofaunal bioturbation is suppressed, thus allowing the laminated fabric within the sediment to be preserved. Suboxic conditions may sustain, in addition to low oxygen tolerant meio(micro)faunas, also polychaete and nematode taxa. "Microaerophilic" bacteria associations, including cyanobacteria and sulfur bacteria (among which extant matforming taxa are well known) can also adapt to these very low oxygen concentrations (Tyson and Pearson 1991).

\section{Allochthonous platform-derived elements}

The laminite lithofacies bears scattered carbonate nodules containing densely packed skeletal grains of shallow-water benthic biota (Fig. 9). These carbonate nodules are flattened, usually $2-4 \mathrm{~cm}$ in diameter, and are sometimes affected by patchy replacement by dolomite or chalcedonic quartz. Boundaries between nodules and enclosing matrix are irregular and sometimes accentuated by dark seams suggesting dissolution. Wirz (1945) interpreted these nodules ("Knollen" of Wirz 1945, p. 61) as autochthonous and related to winnowing processes. On the contrary, Furrer (1999a, 2001b) described similar nodules as clumpy concentrations of ostracods, foraminifers and calcareous algae, interpreting them as regurgitations of fish.

The so far investigated carbonate nodules show a bioclastic packstone to grainstone texture (SMF-18 microfacies type; Flügel 2004). Skeletal grains consist of dasycladalean algae, sponges, echinoderms, bivalves, foraminifers and ostracods. Peloids are frequent.

Dasycladalean fragments (Fig. 9h) show evident annulation. Even though typical Diplopora-like forms with trichophorous laterals are present, most fragments show acrophorous to phloiophorous branches. In accordance with the emendation of Güvenç (1979), this latter character prevents from an assignment to the genus Diplopora. For such "diplopors" with phloiophorous laterals the new genus name Pseudodiplopora has been proposed (Bucur and Enos 2001).

Benthic foraminifers (Fig. 9a, g) belong to Hoyenella gr. sinensis (Ho 1959), Endotriadella wirzi (Koehn-Zaninetti 1968), Endotriada sp., "Trochammina" almtalensis (Koehn-Zaninetti 1969), Cornuspira sp. and Pseudobolivina globosa (Kristan-Tollmann 1973 sensu Salaj et al. 1983). Thick-walled Nodosariidae and undetermined microgranular, elongate forms are also present. Miliolid foraminifers like Hoyenella are typical for restricted shallow-waters habitats such as backreef and shallow lagoonal environments (Maurer and Rettori 2002), since the porcelaneous wall is thought to protect the cytoplasm by scattering the short wavelength of ultraviolet light (Armostrong and Brasier 2005). Endotriadella is regarded as living infaunally in shallow-marine conditions (Jones and Charnock 1985). As dasycladaleans thrive in shallow-marine waters down to 10-12 $\mathrm{m}$ depth but show mass occurrences only down to $6 \mathrm{~m}$ depth (Piros and Preto 2008), the presence of these algae indicates a source area located at very shallow depths.

Dasycladalean algae, sponges, echinoderms, bivalves, foraminifers and ostracods have widely been reported from the Salvatore Dolomite (Bernoulli 1964; Zorn 1971). Therefore, these shallow-water assemblages are interpreted as platform-derived, having been swept into the basin from 
Fig. 9 Allochthonous platformderived elements.

a "Trochammina" almtalensis (Koehn-Zaninetti 1969).

b Endotriada sp. c Hoyenella gr. sinensis (Ho 1959).

d Cornuspira sp.

e, f Endotriadella wirzi

(Koehn-Zaninetti 1968).

g Pseudobolivina globosa

(Kristan-Tollmann 1973 sensu

Salaj et al. 1983).

h Dasycladalean fragment.

i Ostracod packstone. Scale bars

$100 \mu \mathrm{m}(\mathbf{a}-\mathbf{g}) ; 500 \mu \mathrm{m}(\mathbf{h}, \mathbf{i})$
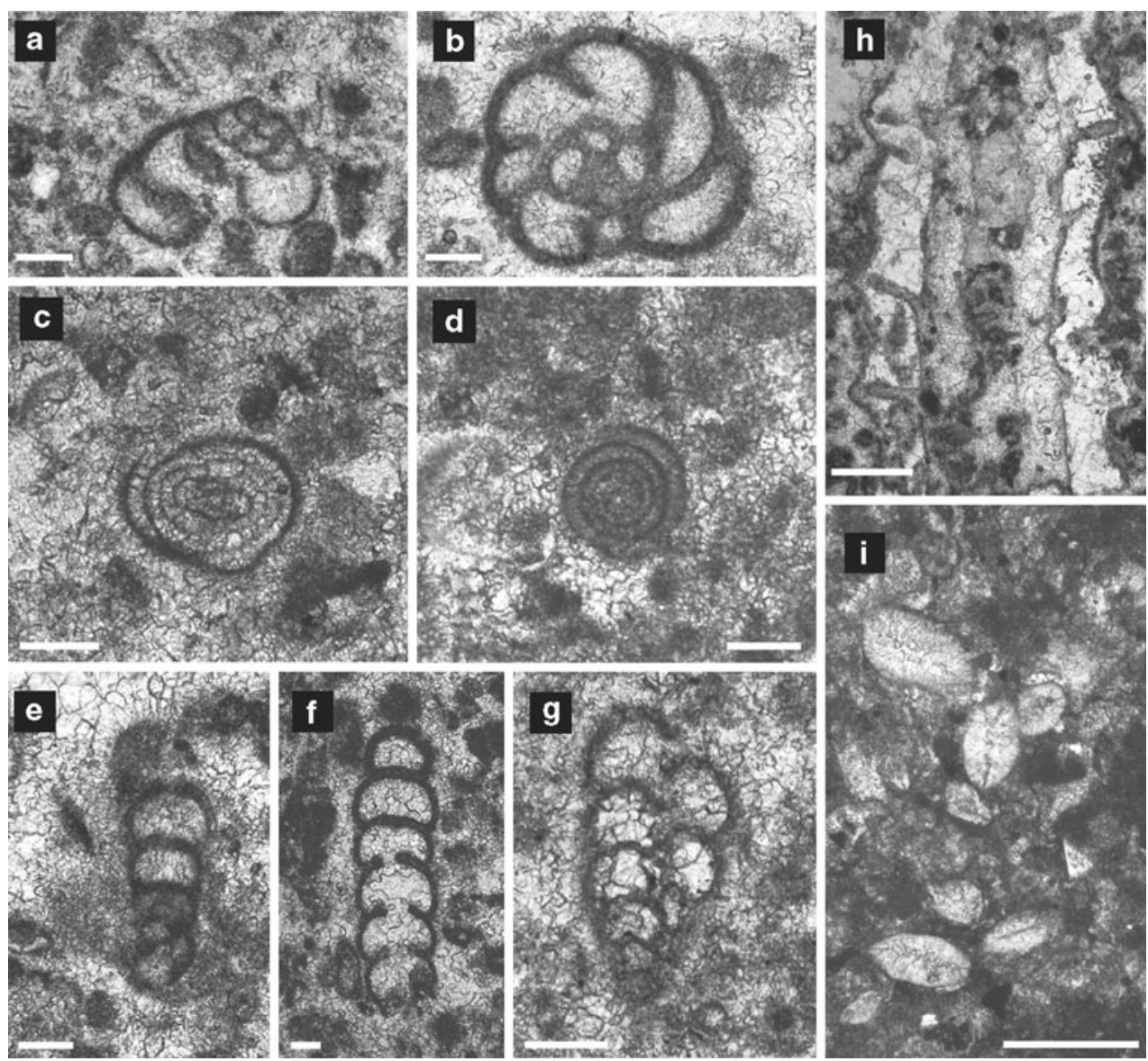

the directly adjoining Salvatore platform, presumably during storm events.

\section{Conclusions and outlook}

The studied section of the Cassina beds records a continuous background sedimentation (laminite lithofacies) mirroring fluctuating but generally severely oxygendepleted conditions on the bottom of a basin below wave base and adjacent to a shallow-water carbonate platform from which a recurrent carbonate supply reached the basin floor, contributing to the sediment lamination (Fig. 10). Vertebrate assemblages and the lack of stenohaline invertebrates point to an environment with limited connection to the open sea. Episodic, short-lived depositional events occur randomly and are related to sediment input from basin margins (turbidite lithofacies) and to volcanic activity (tephra lithofacies). Terrestrial plant remains suggest the presence of relatively far-away emerged areas covered with vegetation. Widespread occurrence of carbonate nodules mirrors a pulsating input from the adjoining Salvatore platform, from which shallow-water, platformrelated benthic taxa were washed into the basin. A mosaic of biostratinomic processes affects the vertebrate skeletons and the detailed pathways of the process clearly vary between representatives of different species. Disintegration patterns are mainly similar to those resulting from anaerobic-decay processes caused by bacteria. Only occasionally, a limited influence of weak bottom currents cannot be ruled out, whereas conclusive evidence of scavenging is missing. The generally excellent preservation of fish skeletons is ascribed to early cessation of decay after death, most probably due to the growth of microbial mats. Even preservation patterns resulting in bone dispersal may best be related to reduced bio-armouring of the carcasses rather than to scavenging activity.

Micropalaeontological analysis of the background sedimentation highlights the episodic occurrence of thinshelled nodosariid foraminifers, which are regarded as autochthonous, facultative anaerobic biota. A quasi-anaerobic benthic biofacies of this kind is documented for the first time from the Monte San Giorgio area. Fluctuating anoxic to temporarily suboxic (sensu Tyson and Pearson 1991) conditions are suggested as having fostered the episodic colonization of the seafloor by the extremely lowoxygen tolerant thin-shelled foraminifers. However, either oxygen values were too low or the sufficiently oxygenated 


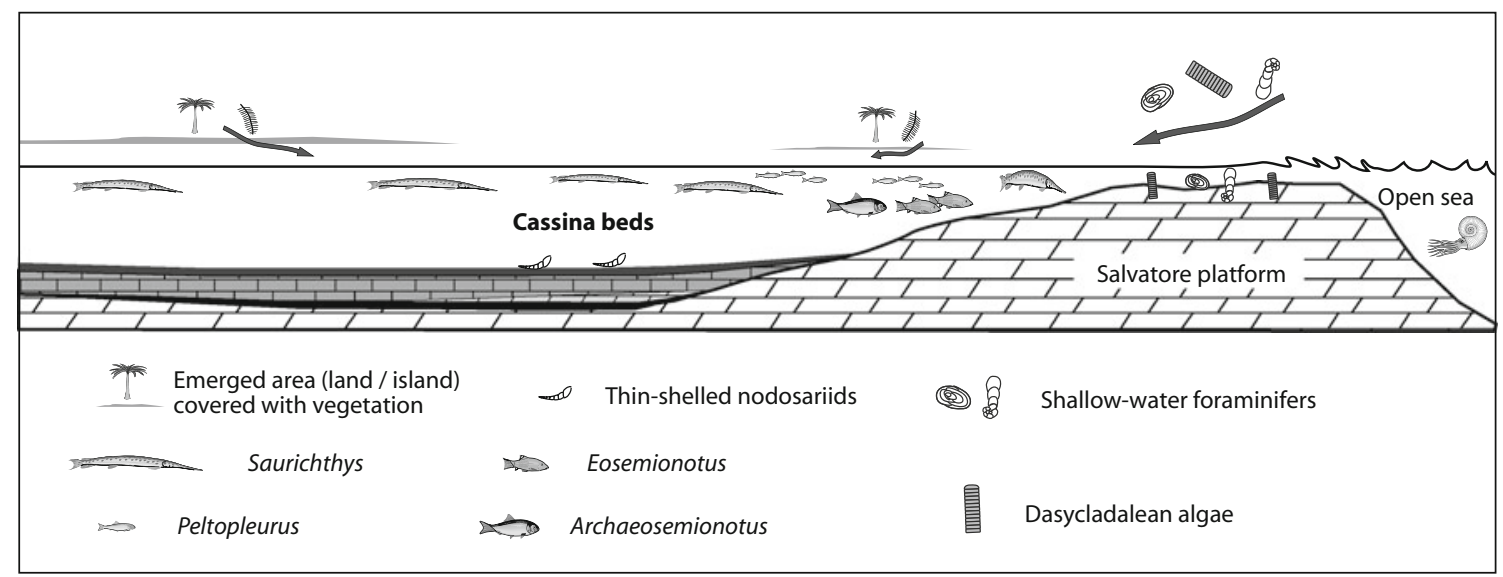

Fig. 10 Schematic palaeoenvironmental interpretation of the Cassina beds, deposited in a restricted basin with oxygen-depleted bottomwaters and separated from the open ocean by the shallow-water Salvatore carbonate platform. A diversified fish fauna with various feeding strategies dwelled in the surface waters whereas thin-shelled nodosariid foraminifers temporarily colonized the muddy seafloor under anoxic to suboxic conditions. Platform-related shallow-water benthic taxa were washed into the basin by storms. Plant remains

periods were too short to allow colonization by a more diverse benthic macrofauna, even including the opportunistic thin-shelled "paper-pecten" dysaerobic bivalves. The described oxygen-deficient conditions are also consistent with the suggested development of microbial mats. The latter, in turn, may have sustained the opportunistic meiofauna, without being virtually damaged, and may have contributed to protect the vertebrate carcasses against disintegration ("microbial shroud" effect). Proliferation and preservation of microbial mats may have been promoted by the absence of ecological competition, such as grazing and bioturbation by macrofaunal biota.

The present paper is a preliminary account of the first 3 years of excavations in the upper part of the Cassina beds. Therefore, the results must be regarded as workinghypotheses for further investigations, which will be carried out in the Meride Limestone but they need to be refined as more data become available. However, the preliminary results emphasize that sediment microfabric and benthic macrofauna composition alone become an inadequate proxy for bottom-water palaeo-oxygenation as the values of the latter approach anoxia, because of its insufficient resolution power in extremely oxygen-depleted regimes which exclude macrofauna and yet allow micro(meio)faunas to survive or even to thrive. Many aspects, only roughly outlined in the present paper, will be studied in greater detail and are expected to provide a better understanding of both the palaeogeography and the palaeoecology of the basin and its margins. In this respect, the investigation of platform-derived nodules, scattered within the background sedimentation, represents a document the presence of emerged areas covered with vegetation. The geometry of the basin can only roughly be inferred. Extensional tectonics has been assumed as a controlling factor for the intraplatform basin but relevant field evidences are missing in the Monte San Giorgio area, where alpine faults and discontinuity of outcrops preclude a detailed reconstruction of the basin to platform transition. Lithological patterns as in Fig. 2. Not to scale

promising tool for reconstructing the missing facies transitions between the Meride Limestone basin and the Salvatore platform. The ongoing study of plant remains might reveal new Triassic species and allow a completely new insight into the vegetation cover of the emerged areas. Comparative taphonomical studies of the same fossil species throughout the entire Cassina beds can further characterize the biostratinomic evolution in relation to changing bottom-water conditions. Stable isotope and organic geochemistry, cross-correlated with palynofacies analysis and carried out throughout the entire Meride Limestone sequence, are expected to shed more light on the palaeogeographic setting and on the evolution of the basin.

Acknowledgments During the first 3 years of excavations in the upper part of the Cassina beds, the author benefited from the help of colleagues and students from Swiss, German and Italian universities. He is indebted to Heinz Furrer, Silvio Renesto, Cristina Lombardo, Roberto Rettori, Toni Bürgin, Adriana Lòpez-Arbarello and Evelyn Kustatscher for the stimulating discussions about different aspects of the Cassina excavation, and to Remo Pagani, the landowner at Cassina, for his enthusiastic interest in the excavations. The author would like to acknowledge the hard work and unconditional commitment of many volunteers during the field work; nothing would have been possible without Urs Oberli, Sergio Pezzoli, Sergio Rampinelli, Margrit Pfister, and the many other "Cassina enthusiasts". Many thanks to Stefano Doninelli (commissione parrocchiale Monte San Giorgio) for having friendly placed the Adenofora mountain refuge at our disposal, and to the municipality of Meride for the logistic support. Earlier drafts of the manuscript benefited from careful re-readings by Peter Baumgartner, Daniel Bernoulli and Silvio Renesto. The preparation of vertebrate and plant fossils was carried out by Heinz Lanz, Urs Oberli, Sergio Rampinelli, Debora Tollardo, Luca Zulliger, and the author. Financial support was granted by the Dipartimento del territorio del Cantone Ticino (Museo Cantonale di 
Storia Naturale) and the Swiss Federal Office for the Environment (FOEN). The author is grateful to the reviewers Rainer Brandner and Heinz Furrer, and to the editors Andreas Wetzel and Daniel Marty for constructive comments on the manuscript, which greatly improved the paper.

\section{References}

Allison, P. A., Wignall, P. B., \& Brett, C. E. (1995). Palaeooxygenation: Effects and recognition. In D. W. J. Bosence \& P. A. Allison (Eds.), Marine palaeoenvironmental analysis from fossils (pp. 97-112). Bath: The Geological Society.

Armostrong, H. A., \& Brasier, M. D. (2005). Microfossils (296 pp). Malden: Blackwell.

Bernasconi, S. M. (1994). Geochemical and microbial controls on dolomite formation in anoxic environments: A case study from the Middle Triassic (Ticino, Switzerland). Contributions to sedimentology, 19, 1-109. E. Schweizerbart. Stuttgart.

Bernhard, J. M., \& Reimers, C. E. (1991). Benthic foraminiferal population fluctuations related to anoxia: Santa Barbara Basin. Biogeochemistry, 15, 127-149.

Bernhard, J. M., \& Sen Gupta, B. K. (1999). Foraminifera of oxygendepleted environments. In B. K. Sen Gupta (Ed.), Modern foraminifera (pp. 201-216). Dordrecht: Kluwer.

Bernoulli, D. (1964). Zur Geologie des Monte Generoso. Ein Beitrag zur Kenntnis der südalpinen Sedimente. Beiträge zur Geologischen Karte der Schweiz, N.F., 118, 1-134.

Bernoulli, D., Govi, M., Graeter, P., Lehner, P., Reinhard, M., \& Spicher, A. (1976). Geologischer Atlas der Schweiz 1:25000, Blatt 1353 Lugano (Atlasblatt 69). Schweizerische Geologische Kommission.

Bowser, S. S., McGee-Russel, S. M., \& Rieder, C. L. (1985). Digestion of prey in foraminifera is not anomalous: A correlation of light microscopic, cytochemical and HVEM techniques to study phagotrophy in two allogromiids. Journal of Ultrastructure and Molecular Structure Research, 94, 149-160.

Brack, P., \& Rieber, H. (1993). Towards a better definition of the Anisian/Ladinian boundary: New biostratigraphic data and correlations of boundary sections from the Southern Alps. Eclogae Geologicae Helvetiae, 86, 415-527.

Brack, P., Rieber, H., Mundil, R., Blendinger, W., \& Maurer, F. (2007). Geometry and chronology of growth and drowning of Middle Triassic carbonate platforms (Cernera and Bivera/ Clapsavon) in the Southern Alps (northern Italy). Swiss Journal of Geosciences, 100, 327-347.

Brack, P., Rieber, H., Nicora, A., \& Mundil, R. (2005). The Global boundary Stratotype Section and Point (GSSP) of the Ladinian Stage (Middle Triassic) at Bagolino (Southern Alps, Northern Italy) and its implications for the Triassic time scale. Episodes, 28, 233-244.

Brack, P., Rieber, H., \& Urlichs, M. (1999). Pelagic successions in the Southern Alps and their correlation with the Germanic Middle Triassic. In G. H. Bachmann \& I. Lerche (Eds.), Epicontinental Triassic. Zentralblatt für Geologie und Paläontologie (1998) Teil 1 (pp. 853-876). Stuttgart: E. Schweizerbart.

Brett, C. E., \& Baird, G. C. (1986). Comparative taphonomy: A key to paleoenvironmental interpretation based on fossil preservation. Palaios, 1, 207-227.

Brühwiler, T., Hochuli, P. A., Mundil, R., Schatz, W., \& Brack, P. (2007). Bio- and chronostratigraphy of the Middle Triassic Reifling Formation in the westernmost Northern Calcareous Alps. Swiss Journal of Geosciences, 100, 443-455.

Brusca, C., Gaetani, M., Jadoul, F., \& Viel, G. (1981). Paleogeografia e metallogenesi del Triassico Sudalpino. In P. Omenetto (Ed.),
Correlazioni tra paleogeografia e mineralizzazioni. Memorie della Società Geologica Italiana, 22, 65-82.

Bucur, I. I., \& Enos, P. (2001). Middle Triassic dasyclad algae from Guizhou, China. Micropaleontology, 47, 317-338.

Bürgin, T. (1992). Basal Ray-finned fishes (Osteichthyes, Actinopterygii) from the Middle Triassic of Monte San Giorgio (Canton Tessin, Switzerland). Schweizerische Paläontologische Abhandlungen, 114, 1-164.

Bürgin, T. (1995). Actinopterygian fishes (Osteichthyes; Actinopterygii) from the Kalkschieferzone (Uppermost Ladinian) near Meride (Canton Ticino, Southern Switzerland). Eclogae geologicae Helvetiae, 88, 803-826.

Bürgin, T. (1999). Middle Triassic marine fish faunas from Switzerland. In G. Arratia \& H.-P. Schultze (Eds.), Mesozoic fishes 2systematics and fossil record (pp. 481-494). München: Pfeil.

Bürgin, T. (2004). Eosemionotus ceresiensis sp. nov., a new semionotiform fish (Actinopterygii, Halecostomi) from the Middle Triassic of Monte San Giorgio (Southern Switzerland). In G. Arratia \& A. Tintori (Eds.), Mesozoic fishes 3-systematics, paleoenvironments and biodiversity (pp. 239-251). München: Pfeil.

Bürgin, T., Eichenberger U., Furrer. H., \& Tschanz K. (1991). Die Prosanto-Formation-eine fischreiche Fossil-Lagerstätte in der Mitteltrias der Silvretta-Decke (Kanton Graubunden, Schweiz). Eclogae geologicae Helvetiae, 84, 921-990.

Buzas, M. A., Hayek, L. C., Reed, S. A., \& Jett, J. A. (2002). Foraminiferal densities over five years in the Indian River Lagoon, Florida: A model of pulsating patches. Journal of Foraminiferal Research, 32, 62-93.

Carroll, R. L., \& Gaskill, P. (1985). The nothosaur Pachypleurosaurus and the origin of plesiosaurs. Philosophical Transactions of the Royal Society of London B, 309, 343-393.

Crasquin-Soleau, S., \& Kershaw, S. (2005). Ostracod fauna from the Permian-Triassic boundary interval of South China (Huaying Mountains, eastern Sichuan Province): Palaeoenvironmental significance. Palaeogeography, Palaeoclimatology, Palaeoecology, 217, 131-141.

Deeke, W. (1889). Über Fische aus verschiedenen Horizonten der Trias. Palaeontographica, 35, 97-138.

Dunham, R. J. (1962). Classification of carbonate rocks according to depositional texture. In W. E. Ham (Ed.), Classification of carbonate rocks. American Association of Petroleum Geologists Memoir, 1, 108-121.

Elder, R. L., \& Smith, G. R. (1988). Fish taphonomy and environmental inference in paleolimnology. Palaeogeography, Palaeoclimatology, Palaeoecology, 62, 577-592.

Flügel, E. (2004). Microfacies of carbonate rocks. Analysis interpretation and application (976 pp). Heidelberg: Springer.

Frauenfelder, A. (1916). Beiträge zur Geologie der Tessiner Kalkalpen. Eclogae Geologicae Helvetiae, 14, 247-367.

Furrer, H. (1995). The Kalkschieferzone (Upper Meride Limestone; Ladinian) near Meride (Canton Ticino, Southern Switzerland) and the evolution of a Middle Triassic intraplatform basin. Eclogae Geologicae Helvetiae, 88, 827-852.

Furrer, H. (1999a). New excavations in marine Middle Triassic Fossil-Lagerstätten at Monte San Giorgio (Canton Ticino, Southern Switzerland) and the Duncan Mountains near Davos (Canton Graubünden, Eastern Switzerland). In S. Renesto (Ed.), Third international symposium on lithographic limestones (pp. 85-88). Bergamo: Rivista del Museo Civico di Scienze naturali "Enrico Caffi".

Furrer, H. (1999b). Aktuelle Grabungen in den Unteren MerideKalken bei Acqua del Ghiffo. In Zoologisches Museum der Universität Zürich (Ed.), Fossilien und ihre Forschung in Geschichte und Gegenwart (pp. 87-103). Zürich: Zoologisches Museum der Universität Zürich. 
Furrer, H. (2001a). Fossil-Lagerstätten in the Lower Meride Limestone, Ladinian. Guide to the field trip to Acqua del Ghiffo near Crocifisso, Meride TI. International Meeting on Mesozoic Fishes 3-Systematics, Paleoenvironments and Biodiversity (pp. 1-11). Serpiano.

Furrer, H. (2001b). Taphonomy and palaeoecology of fish beds in the Lower Meride Limestone (Ladinian, Middle Triassic) on Monte San Giorgio (Canton Ticino, Southern Switzerland). In A. Tintori (Ed.), International meeting on Mesozoic fishes 3systematics, paleoenvironments and biodiversity (p. 29). Serpiano: Abstract Book.

Furrer, H. (2003). Der Monte San Giorgio im Südtessin-Vom Berg der Saurier zur Fossil-Lagerstãtte internationaler Bedeutung. Neujahrsblatt der Naturforschenden Gesellschaft Zh, 206, 1-64.

Furrer, H., Schaltegger, U., Ovtcharova, M., \& Meister, P. (2008). $\mathrm{U}-\mathrm{Pb}$ zircon age of volcaniclastic layers in Middle Triassic platform carbonates of the Austroalpine Silvretta nappe (Switzerland). Swiss Journal of Geosciences, 101, 595-603.

Gaetani, M., Gnaccolini, M., Poliani, G., Grignani, D., Gorza, M., \& Martellini, L. (1992). An anoxic intraplatform basin in the Middle Triassic of Lombardy (Southern Alps, Italy): Anatomy of a hydrocarbon source. Rivista Italiana di Paleontologia $e$ Stratigrafia, 97, 329-354.

Gall, J.-C. (2001). Role of microbial mats. In D. E. G. Briggs \& P. R. Crowther (Eds.), Palaeobiology II (pp. 280-284). Bodmin: Blackwell.

Gianotti, R., \& Tannoia, G. (1988). Elementi per una revisione stratigrafico-paleontologica del Trias medio superiore della regione compresa tra il Lario e il Ceresio. Atti Ticinensi di Scienze della Terra, 31, 434-445.

Gooday, A. J., Bernhard, J. M., Levin, L. A., \& Shur, S. B. (2000). Foraminifera in the Arabian Sea oxygen minimum zone and other oxygen-deficient settings: Taxonomic composition, diversity and relation to metazoan faunas. Deep Sea Research Part II: Topical Studies in Oceanography, 47, 25-54.

Gozzi, E. (2001). Swimming biomechanic of the Norian (Late Triassic) Saurichthys (Actinopterygii): Cruisers or improved fast-starters? In A. Tintori (Ed.), International Meeting on Mesozoic Fishes 3-Systematics, Paleoenvironments and Biodiversity (p. 37). Serpiano: Abstract Book.

Güvenç T. (1979). Dasycladacées métaspondiles du Paléozoiques supérieur et du Trias. Bulletin des Centres de Recherches Exploration Production Elf-Aquitaine, 3, 625-637.

Hänni, K. (2004). Die Gattung Ceresiosaurus. Ceresiosaurus calcagnii Peyer und Ceresiosaurus lanzi n. sp. (Lauriosauridae, Sauropterygia) (147 pp). Zürich: Vdf Hochschulverlag ETH Zürich.

Hellmann, K. N., \& Lippolt, H. J. (1981). Calibration of the Middle Triassic time scale by conventional $\mathrm{K}-\mathrm{Ar}$ and ${ }^{40} \mathrm{Ar} /{ }^{39} \mathrm{Ar}$ dating of alkali feldspars. Journal of Geophysics, 50, 73-88.

Hochuli, P. A., \& Roghi, G. (2002). A palynological view on the Anisian/Ladinian boundary-new results from the Seceda section (Dolomites, Northern Italy). I. U. G. S. Commission on Triassic Stratigraphy, STS/IGCP, Field Meeting (pp. 29-30). Veszpröm: Program \& Abstracts.

Holcova, K. (1997). Can detailed sampling and taphonomical analysis of foraminiferal assemblages offer new data for paleoecological interpretation? Revue de Micropaléontologie, 40, 313-329.

Jones, W., \& Charnock, M. A. (1985). Morphogroups of agglutinating foraminifera. Their life positions and feeding habits and potential applicability in (paleo)ecological studies. Revue de Paléobiologie, 42, 311-320.

Josefson, A. B., \& Widbom, B. (1988). Differential response of benthic macrofauna and meiofauna to hypoxia in the Gullmar fjord basin. Marine Biology, 100, 31-40.
Kahio, K. (1994). Benthic foraminiferal dissolved-oxygen index and dissolved-oxygen levels in the modern ocean. Geology, 22, 719722.

Koutsoukos, E. A. M., Leary, P. N., \& Hart, M. B. (1990). Latest Cenomanian-earliest Turonian low-oxygen tolerant foraminifera: A case-study from the Sergipe basin (N.E. Brasil) and the western Anglo-Paris Basin (southern England). Palaeogeography, Palaeoclimatology, Palaeoecology, 77, 145-177.

Krzeminski, W., \& Lombardo, C. (2001). New fossil Ephemeroptera and Coleoptera from the Ladinian (Middle Triassic) of Canton Ticino (Switzerland). Rivista Italiana di Paleontologia e Stratigrafia, 107, 69-78.

Kuhn-Schnyder, E. (1974). Die Triasfauna der Tessiner Kalkalpen. Neujahrsblatt der Naturforschenden Gesellschaft Zürich, 176, 1119.

Lethiers, F., \& Whatley, R. (1994). The use of Ostracoda to reconstruct the oxygen levels of the Late Paleozoic oceans. Marine Micropaleontology, 24, 57-69.

Lombardo, C. (2001). Peltopleuriformes: Problems in the definition of a group. In A. Tintori, (Ed.). International Meeting on Mesozoic Fishes 3-Systematics, Paleoenvironments and Biodiversity (p. 48). Serpiano: Abstract Book.

Lombardo, C. (2002). Caelatichthys gen. n.: A new palaeonisciform from the Middle Triassic of Northern Italy and Canton Ticino (Switzerland). Rivista Italiana di Paleontologia e Stratigrafia, 108, 399-414.

Lombardo, C., \& Tintori, A. (2004). New Perleidiforms from the Triassic of the Southern Alps and the revision of Serrolepis from the Triassic of Wüttemberg (Germany). In G. Arratia \& A. Tintori (Eds.), Mesozoic fishes 3-systematics, paleoenvironments and biodiversity (pp. 179-196). München: Pfeil.

Maurer, F., \& Rettori, R. (2002). Middle Triassic Foraminifera from the Seceda Core (Dolomites, Northern Italy). Rivista Italiana di Paleontologia e Stratigrafia, 108, 391-398.

McGrew, P. O. (1975). Taphonomy of Eocene fish from Fossil Basin, Wyoming. Fieldiana: Geology, 33, 257-270.

Moodley, L., \& Hess, C. (1992). Tolerance of infaunal benthic foraminifera for low and high oxygen concentrations. Biological Bulletin, 183, 94-98.

Moodley, L., Van der Zwaan, G. J., Herman, P. M. J., Kempers, L., \& Van Breugel, P. (1997). Differential response of benthic meiofauna to anoxia with special reference to Foraminifera (Protista: Sarcodina). Marine Ecology Progress Series, 158, $151-163$

Müller, W., Schmid, R., \& Vogt, P. (1964). Vulkanogene Lagen aus der Grenzbitumenzone (Mittlere Trias) des Monte San Giorgio in den Tessiner Kalkalpen. Eclogae geologicae Helvetiae, 57, 431-450.

Müller-Merz, E., Berger, J.-P., Furrer, H., \& Meyer, C. (2005). Paläontologie und Umwelt (92 pp). Zürich: Vdf Hochschulverlag ETH Zürich.

Mundil, R., Brack, P., Meier, M., Rieber, H., \& Oberli, F. (1996). High resolution U-Pb dating of Middle Triassic volcaniclastics: Time-scale calibration and verification of tuning parameters for carbonate sedimentation. Earth and Planetary Science Letters, $141,137-151$.

Murray, J. (2006). Ecology and applications of benthic foraminifera (426 pp). Cambridge: Cambridge University Press.

Mutti, M., \& Weissert, H. (1995). Triassic monsoonal climate and its signature in Ladinian-Carnian carbonate platforms. Journal of Sedimentary Research, 65, 357-367.

Nosotti, S. (2007). Tanystropheus longobardicus (Reptilia, Protosauria): Re-interpretations of the anatomy based on new specimens from the Middle Triassic of Besano (Lombardy, Northern Italy). Memorie della Società Italiana di Scienze Naturali e del Museo Civico di Storia Naturale di Milano, 35, 1-88. 
Oschmann, W. (1991). Anaerobic-poikiloaerobic-aerobic: A new zonation for modern and ancient neritic redox facies. In G. Einsele, W. Ricken, \& A. Seilacher (Eds.), Cycles and events in stratigraphy (pp. 565-571). Berlin: Springer.

Oschmann, W. (2001). Oxygen in the ocean. In D. E. G. Briggs \& P. R. Crowther (Eds.), Palaeobiology II (pp. 470-472). Bodmin: Blackwell

Peyer, B. (1937). Die Triasfauna der Tessiner Kalkalpen XII. Macronemus bassanii Nopcsa. Abhandlungen der Schweizerischen Paläontologischen Gesellschaft, 59, 1-140.

Picotti, V., Capozzi, R., Bertozzi, G., Mosca, F., Sitta, A., \& Tornaghi, M. (2007). The Miocene petroleum system of the Northern Apennines in the central Po Plain (Italy). In O. Lacombe, J. Lavé, F. Roure, \& J. Vergés (Eds.), Thrust belts and foreland basins. From fold kinematics to hydrocarbon systems (pp. 117-131). Heidelberg: Springer.

Piros, O., \& Preto, N. (2008). Dasycladalean algae distribution in ammonoid-bearing Middle Triassic platforms (Dolomites, Italy). Facies, 54, 581-595.

Renesto, S., \& Stockar, R. (2009). Exceptional preservation of embryos in the actinopterygian Saurichthys from the Middle Triassic of Monte San Giorgio, Switzerland. Swiss Journal of Geosciences, 102, 323-330.

Renesto, S., Lombardo C., \& Stockar R. (2008). New excavations in the Cassina levels (Monte San Giorgio, Middle Triassic): preliminary reports. 6th Swiss Geoscience Meeting (pp. 129130). Lugano: Abstract Volume.

Rhoads, D. C., \& Morse, J. W. (1971). Evolutionary and ecologic significance of oxygen-deficient marine basins. Lethaia, 4, 413428.

Rieber, H. (1969). Daonellen aus der Grenzbitumenzone der mittleren Trias des Monte San Giorgio (Kt Tessin, Schweiz). Eclogae Geologicae Helvetiae, 62, 657-683.

Rieber, H. (1973). Cephalopoden aus der Grenzbitumenzone (Mittlere Trias) des Monte San Giorgio (Kt Tessin/Schweiz). Schweizerische PaläontologischeAbhandlungen, 93, 1-96.

Rieppel, O. (1985). Die Triasfauna der Tessiner Kalkalpen XXV. Die Gattung Saurichthys (Pisces, Actinopterygii) aus der mittleren Trias des Monte San Giorgio, Kanton Tessin. Schweizerische Paläontologische Abhandlungen, 108, 1-103.

Rieppel, O. (1992). A new species of the genus Saurichthys (Pisces: Actinopterygii) from the Middle Triassic of Monte San Giorgio (Switzerland), with comments on the phylogenetic interrelationships of the genus. Palaentographica A, 221, 63-94.

Rieppel, O. (1998). The Status of Sauropterygian Reptile Genera Ceresiosaurus, Lariosaurus and Silvestrosaurus from the Middle Triassic of Europe. Fieldiana: Geology, 38, 1-46.

Rieppel, O. (2007). On the nothosaurian genera Ceresiosaurus and Lariosaurus. Geologia Insubrica, 10(2), 1-3.

Röhl, H. J., Schmid-Röhl A., Furrer, H., Frimmel, A., Oschmann, W., \& Schwark, L. (2001). Microfacies, geochemistry and palaeoecology of the Middle Triassic Grenzbitumenzone from Monte San Giorgio (Canton Ticino, Switzerland). Geologia Insubrica, $6(1), 1-13$

Salaj, J., Borza, K., \& Samuel, O. (1983). Triassic Foraminifers of the West Carpathians (213 pp). Bratislava: Geologicky Ustav Dioniza Stura.

Sander, M. (1989). The Pachypleurosaurids (Reptilia: Nothosauria) from the Middle Triassic of Monte San Giorgio (Switzerland) with the description of a new species. Philosophical Transactions of the Royal Society of London B, 325, 561-670.

Schatz, W. (2001). Taxonomic significance of biometric characters and the consequences for classification and biostratigraphy, exemplified through moussoneliform daonellas (Daonella, Bivalvia; Triassic). Paläontologische Zeitschrift, 75, 51-70.
Schatz, W. (2005a). Palaeoecology of the Triassic black shale bivalve Daonella - a new insight into an old controversy. Palaegeography, Palaeoclimatology, Palaeoecology, 216, 189-201.

Schatz, W. (2005b). Taxonomie, Paläoökologie und biostratigraphische Anwendung der Daonellen (Bivalvia, Mollusca) aus der Mitteltrias Europas. Schweizerische Paläontologische Abhandlungen, 125, 1-177.

Scheuring, B. W. (1978). Mikrofloren aus den Meridekalken des Mte. San Giorgio (Kanton Tessin). Schweizerische Paläontologische Abhandlungen, 100, 1-205.

Schultze, H.-P., \& Möller, H. (1986). Wirbeltierreste aus dem Mittleren Muschelkalk (Trias) von Göttingen, West-Deutschland. Paläontologische Zeitschrift, 60, 109-129.

Seilacher, A., Reif, W. E., \& Westphal, F. (1985). Sedimentological, ecological and temporal patterns of fossil Lagerstätten. Philosophical Transactions of the Royal Society of London B, 311, 5-23.

Senn, A. (1924). Beiträge zur Geologie des Alpensüdrandes zwischen Mendrisio und Varese. Eclogae Geologicae Helvetiae, 18, 552632.

Sommaruga, A., Hochuli, P. A., \& Mosar, J. (1997). The Middle Triassic (Anisian) conglomerates from Capo San Martino, South of Lugano-Paradiso (Southern Alps, Switzerland). Geologia Insubrica, 2(1), 1-14.

Stockar, R. \& Kustascher, E. (in press). The Ladinian flora from the Cassina beds (Meride Limestone, Monte San Giorgio, Switzerland): preliminary results. Rivista Italiana di Paleontologia $e$ Stratigrafia.

Tintori, A. (1992). Fish taphonomy and Triassic anoxic basins from the Alps: A case history. Rivista Italiana di Paleontologia e Stratigrafia, 97, 393-408.

Tintori, A., \& Lombardo, C. (2007). A new early Semionotidae (Semionotiformes, Actinopterygii) from the Upper Ladinian of Monte San Giorgio area (Southern Switzerland and Northern Italy). Rivista Italiana di Paleontologia e Stratigrafia, 113, 369381.

Tyson, R. V., \& Pearson, T. H. (1991). Modern and ancient continental shelf anoxia: An overview. In R. V. Tyson \& T. H. Pearson (Eds.), Modern and Ancient Continental Shelf Anoxia. Special publication 58 (pp. 1-24). London: Geological Society.

Van der Eem, J. G. L. A. (1983). Aspects of Middle and Late Triassic Palynology. 6 Palynological investigations in the Ladinian and Lower Karnian of the Western Dolomites, Italy. Review of Palaeobotany and Palynology, 39, 189-300.

Whatley, R. C. (1992). The Platycopid signal: A means of detecting kenoxic events using ostracoda. Journal of Micropalaeontology, 10, 181-185.

Wignall, P. B., \& Hallam, A. (1991). Biofacies, stratigraphic distribution and depositonal models of British onshore Jurassic black shales. In R. V. Tyson \& T. H. Pearson (Eds.), Modern and ancient continental shelf anoxia. Special publication 58 (pp. 291-309). London: Geological Society.

Wild, R. (1980). Die Triasfauna der Tessiner Kalkalpen XXIV. Neue Funde von Tanystropheus (Reptilia, Squamata). Schweizerische Paläontologische Abhandlungen, 102, 1-43.

Wilson, M. V. H. (1988). Taphonomic process: Information loss and information gain. Geoscience Canada, 15, 131-148.

Wirz, A. (1945). Die Triasfauna der Tessiner Kalkalpen XV. Beiträge zur Kenntnis des Ladinikums im Gebiete des Monte San Giorgio. Schweizerische Paläontologische Abhandlungen, 65, 1-84.

Wright, V. P. (1992). A revised classification of limestones. Sedimentary Geology, 76, 177-186.

Zorn, H. (1971). Paläontologische, stratigraphische und sedimentologische Untersuchungen des Salvatoredolomits (Mitteltrias) der Tessiner Kalkalpen. Schweizerische Paläontologische Abhandlungen, 91, 1-90. 